Australian Council for Educational Research (ACER)

ACEReSearch

LSAY Research Reports

Longitudinal Surveys of Australian Youth (LSAY)

8-1-1996

Completing school in Australia: trends in the 1990s

Stephen Lamb

ACER

Follow this and additional works at: https://research.acer.edu.au/lsay_research

Part of the Educational Assessment, Evaluation, and Research Commons

Recommended Citation

Lamb, S. (1996). Completing school in Australia: trends in the 1990s. https://research.acer.edu.au/ Isay_research/56

This Report is brought to you by the Longitudinal Surveys of Australian Youth (LSAY) at ACEReSearch. It has been accepted for inclusion in LSAY Research Reports by an authorized administrator of ACEReSearch. For more information, please contact repository@acer.edu.au. 


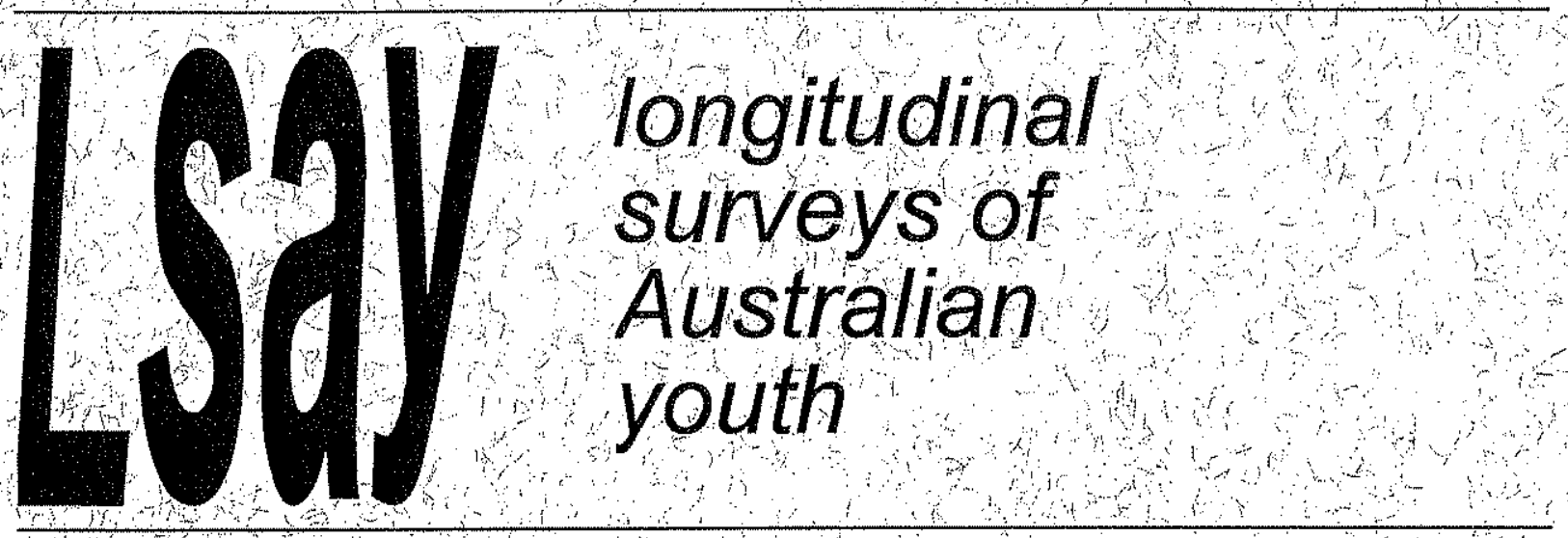

Research Report Nümber 1

\title{
COMPLETING SCHOOL \\ IN AUSTRALIA: \\ TRENDS IN THE 1990S
}

\author{
Stephen Lamb
}

September 1996

\section{ACER}

Australian Council for Educational Research

Copyright Agency Limited (CAL) licensed copy Further copying and

Communication prohibited except on payment of fee per Copy or Commuication

And otherwise in accordance with the licence from CAL to ACER. For more

Information contactCA on (02) 9394-7600 or info@copytightcomau 


\title{
Longitudinal Surveys of Australian Youth
}

Research Report Number 1

\section{COMPLETING SCHOOL IN AUSTRALIA: TRENDS IN THE 1990s}

\author{
Stephen Lamb
}

This report forms part of the Longitudinal Surveys of Australian Youth: a research program that is financially supported by the Commonwealth Department of Employment, Education, Training and Youth Affairs.

The views expressed in this report are those of the author and not necessarily of the Commonwealth Department of Employment, Education, Training and Youth Affairs.

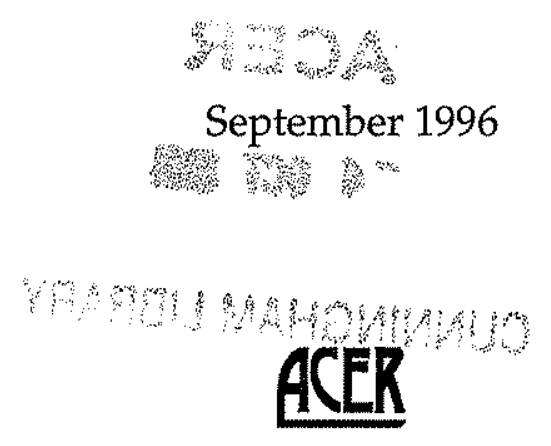

Australian Council for Educational Research 


\section{CONTENTS}

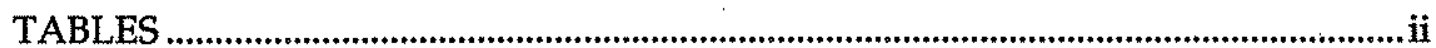

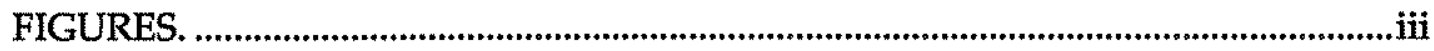

INTRODUCTION

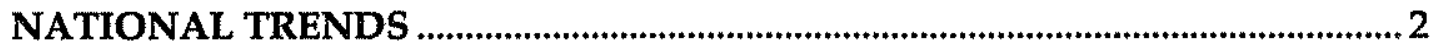

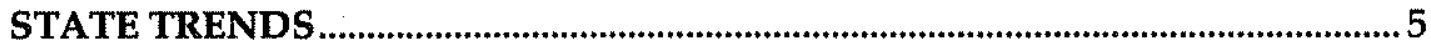

SECTOR TRENDS

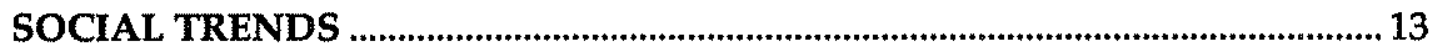

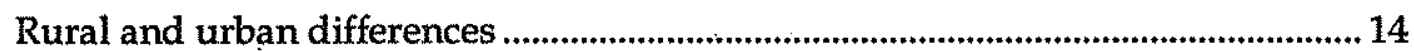

Language background differences ................................................................................ 14

Socioeconomic background differences.............................................................17

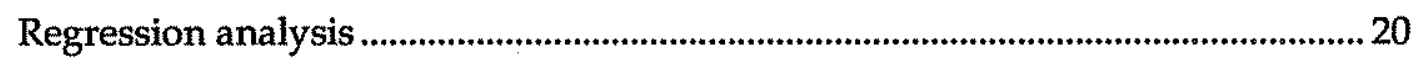

DISCUSSION

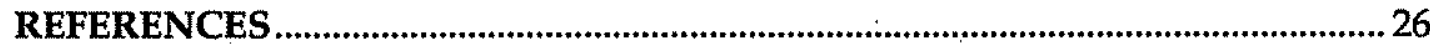




\section{TABLES}

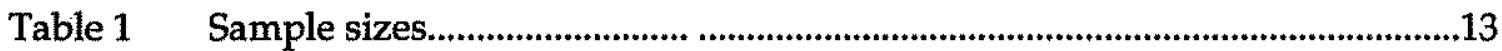

Table 2 Description of Variables.......................................................................................20

Table 3 Logistic regression modelling school completion for 1988,1991 and 1994: males..............................................................................21

Table 4 Logistic regression modelling school completion for

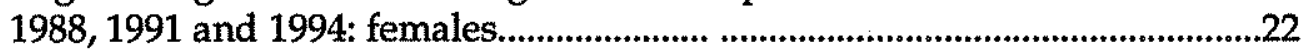

Table 5 Participation in Technical and Further Education of 16 year-olds: Australia, May 1991-1994.....................................................................24 


\section{FIGURES}

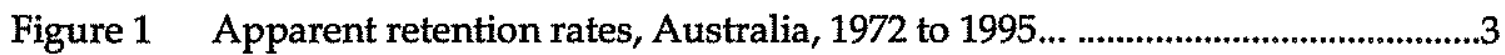

Figure 2 Age participation rates, 17 year-olds, Australia, 1972 to $1995 \ldots . . . . . \ldots \ldots \ldots . . . \ldots \ldots . . . . .4$

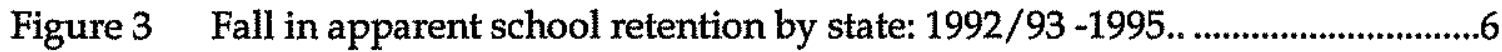

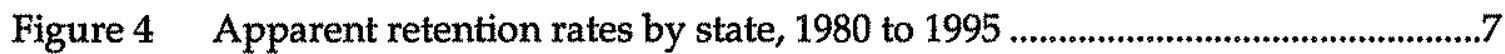

Figure 5 Fall in apparent retention rates for males by state and sector: 1992/93-1995 9

Figure 6 Fall in apparent retention for females by state and sector: 1992/93-1995 .10

Figure 7 Growth of Year 7 enrolments and Year 11 enrolments four years later: non-Catholic private schools, Australia...

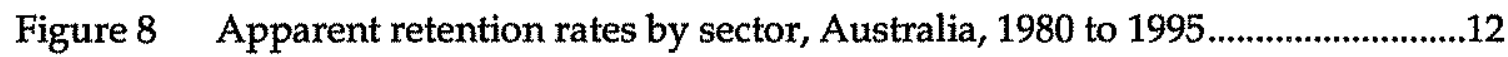

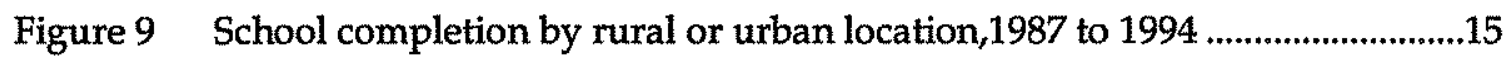

Figure 10 School completion by English-speaking background, 1987-1994...................16

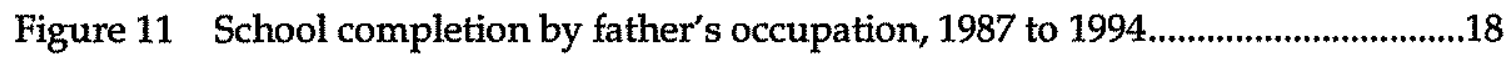

Figure 12 Fall in school completion by father's occupation: 1990/91-1994..................19 


\section{Completing School in Australia: Trends in the 1990s}

\section{INTRODUCTION}

The dramatic growth in school completion that began in the early 1980 s has come to an end. Nationally the proportion of young people remaining to Year 12 grew from approximately one-third at the beginning of the 1980 s to a peak of $77 \%$ in 1992 . Since then it has fallen annually, dropping to a rate of $72 \%$ in 1995 (Australian Bureau of Statistics, 1995). While the substantial growth recorded during the 1980s attracted considerable research attention, relatively little is known about the recent downturn. Has the decline been evenly experienced or has it involved some populations more than others? Has it involved users of particular school systems and to what extent? What have been the origins of the recent falls and their characteristics? These are the questions we take up in this report.

It is important to examine underlying dimensions of the recent drift away from school. While it is unlikely that there will be a return to the low school completion levels of the past, there remains a substantial (well over a quarter of all students who enter school) and growing number of young people who renounce extended schooling. This is the case even though the economic circumstances have not substantially changed in recent times. A weak teenage labour market and high levels of youth unemployment have been features of the Australian economy for some time. While sections of the economy have picked up in the last few years, youth unemployment has remained high and teenage labour market opportunities depressed. Early school leavers continue to be substantially disadvantaged in the competition for work. This suggests that over the last few years there have been stronger influences shaping students' school leaving decisions than the state of the labour market. Studying the recent trends is a preliminary step to establishing why many young people are no longer willing to depend on school as a source of security in the context of a weak youth labour market.

In addition, a sustained downturn in school survival rates increases the need to monitor social differences in school completion, in other words, to continue to use completion as a measure of educational and social equity. As the social base of school completers broadened during the 1980s, survival in school became a less discriminating measure of school activity. Social differences in rates of school completion declined, particularly for girls (Lamb, 1994). Other measures of educational activity such as subject enrolments, pupil performance, access to higher education and the take-up of technical and further education have become more important in measuring differences in school experiences and outcomes (Teese, McLean and Polesel, 1992). Yet, school completion remains an important educational indicator because survival in school is far from universal. Other measures of school outcomes such as entry to higher education or final year results deal with selected populations and need to be interpreted with reference to survival rates. In light of the recent growth in early school leaving, there is a strong need to continue to monitor the numbers of young people completing school and their backgrounds.

To help examine the recent downturn in school completion rates in Australia this report makes use of two sources of data. The first is from the Schools Australia series published by the Australian Bureau of Statistics (ABS). The figures provided by this series are compiled from enrolment information collected from schools by individual state and territory departments of education as well as by the Commonwealth Department of Employment, Education, Training and Youth Affairs. The figures provide aggregate information on school retention and participation by state and school system. The second set of data is from the Australian Youth Survey which is part of a programme of national longitudinal surveys managed by the Australian Council for Educational Research. 
This data provides individual level information, facilitating comparisons based on family background and demographic measures. It will be used to help identify any social patterns associated with the recent downturn in survival to Year 12.

In the following sections data from both sources will be used to document national, state, system, social and gender differences in the recent downturn in school completion rates. We will begin by looking at national patterns using ABS figures.

\section{NATIONAL TRENDS}

The decline in school retention rates is displayed in Figure 1. Nationally the proportion of children remaining to Year 12 peaked in 1992 and has fallen steadily since that time. The trend has been experienced by both males and females, though slightly stronger amongst males. The fall over the four year period from 1992 was $5.8 \%$ for males and $5.1 \%$ for females.

Of course caution is needed in using apparent retention rates to measure the extent of downturn. The ABS figures are not adjusted for population changes due to migration and differences in levels of grade repeating which fluctuate over time. However, the downturn evident in retention rates has also been reflected in the national age participation rates. Participation rates are less affected by migration and grade repeating because they are based on annual estimates of an age population rather than the survival of a cohort over several years. The rates for 17 year-olds are presented in Figure 2. They show a matching pattern of decline since 1992. After a decade of growth, the proportions of 17 year-olds in school across Australia fell by over $2 \%$ across the four years to 1995 . The fall affected males more than females $(3.0 \%$ as against $1.1 \%)$ producing a widening gender gap in school participation. Similar falls were recorded in the rates of participation for 16 year-olds.

The downturn in retention and participation rates is not unprecedented since growth in school completion has not always been upwards. A similar pattern of decline was recorded in the 1970s, largely involving males. As Figures 1 and 2 show, male participation and retention rates fell from 1972 through to the early 1980s while the rates for females slowed during the late 1970s. Underpinned both by growth in apprenticeships, which increased during the 1970s despite economic recession, and by narrowly focused senior school programmes, which failed to appeal to broader populations, teenagers, particularly male teenagers, placed more value on the labour market than on school as a source of economic security (Teese, 1983; COSTAC, 1986; Ainley, Batten and Miller, 1984b). Mounting youth unemployment and a deteriorating teenage labour market did not abate the general decline, although probably weakened its magnitude.

Growth in school retention returned in the early 1980s. Accelerated by recession, sharp increases were recorded following the 1982-83 recession and again following the onset of economic downturn in 1991. Other factors contributed including increased government financial assistance (study allowances) for young people in families of low income and the abolition of unemployment benefits for 16-17 year olds. Important also were changes in school programs. Major changes were made in several states to the provision of the senior secondary school curriculum to accommodate a broader range of students. Together these changes supported a decade of great expansion in senior schooling, a decade in which Australian states moved rapidly and impressively towards developing mass or universal systems of secondary education. The downturn since 1992 indicates that this phase of building has now stalled. 
FIGURE 1: Apparent retention rates, Australia, 1972 to 1995

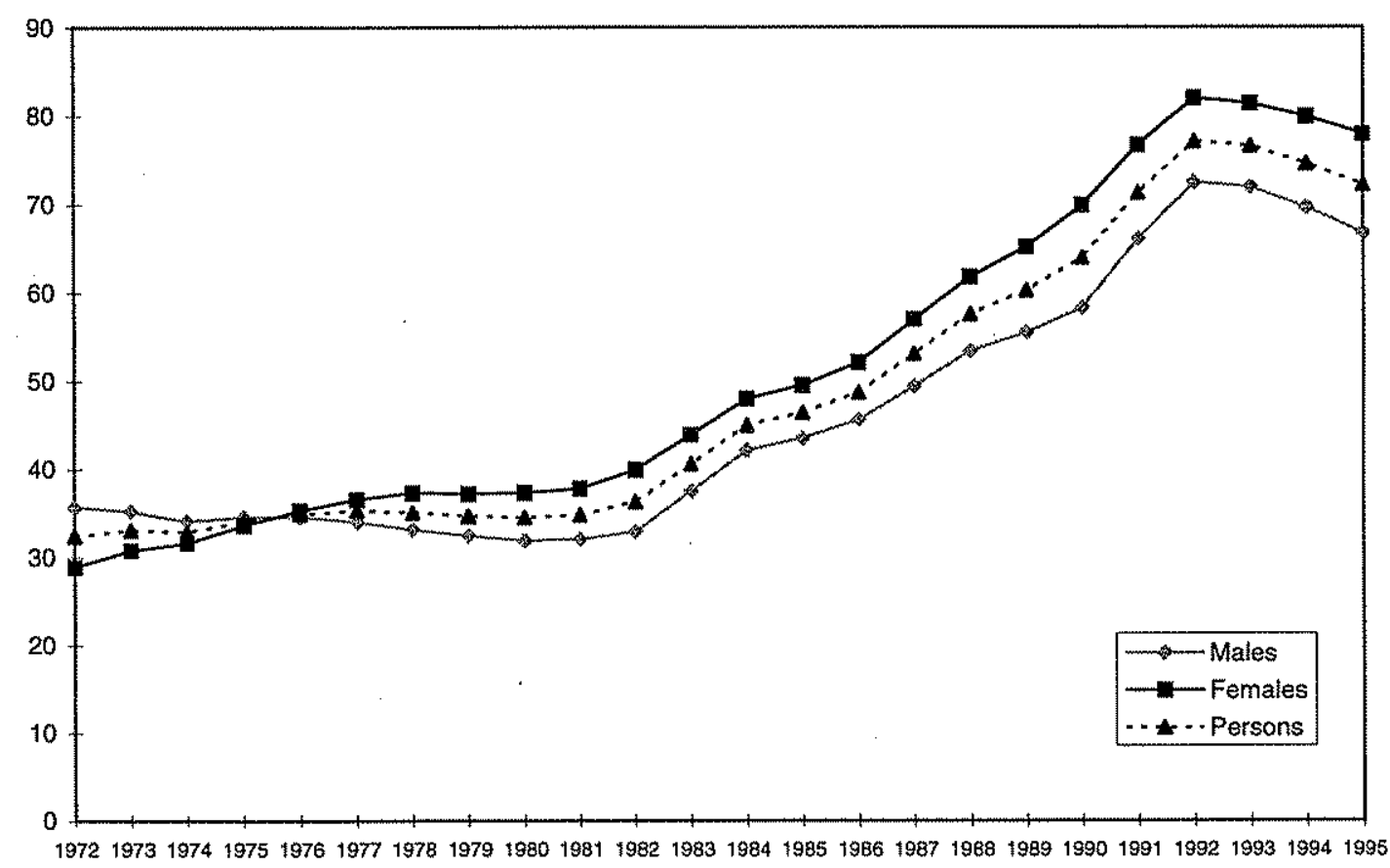

Source: Figures were derived from the Schools Australia Series, Cat. No. 4221.0, published by the Australian Bureau of Statistics. 
FIGURE 2: Age participation rates, 17 year-olds, Australia, 1972 to 1995

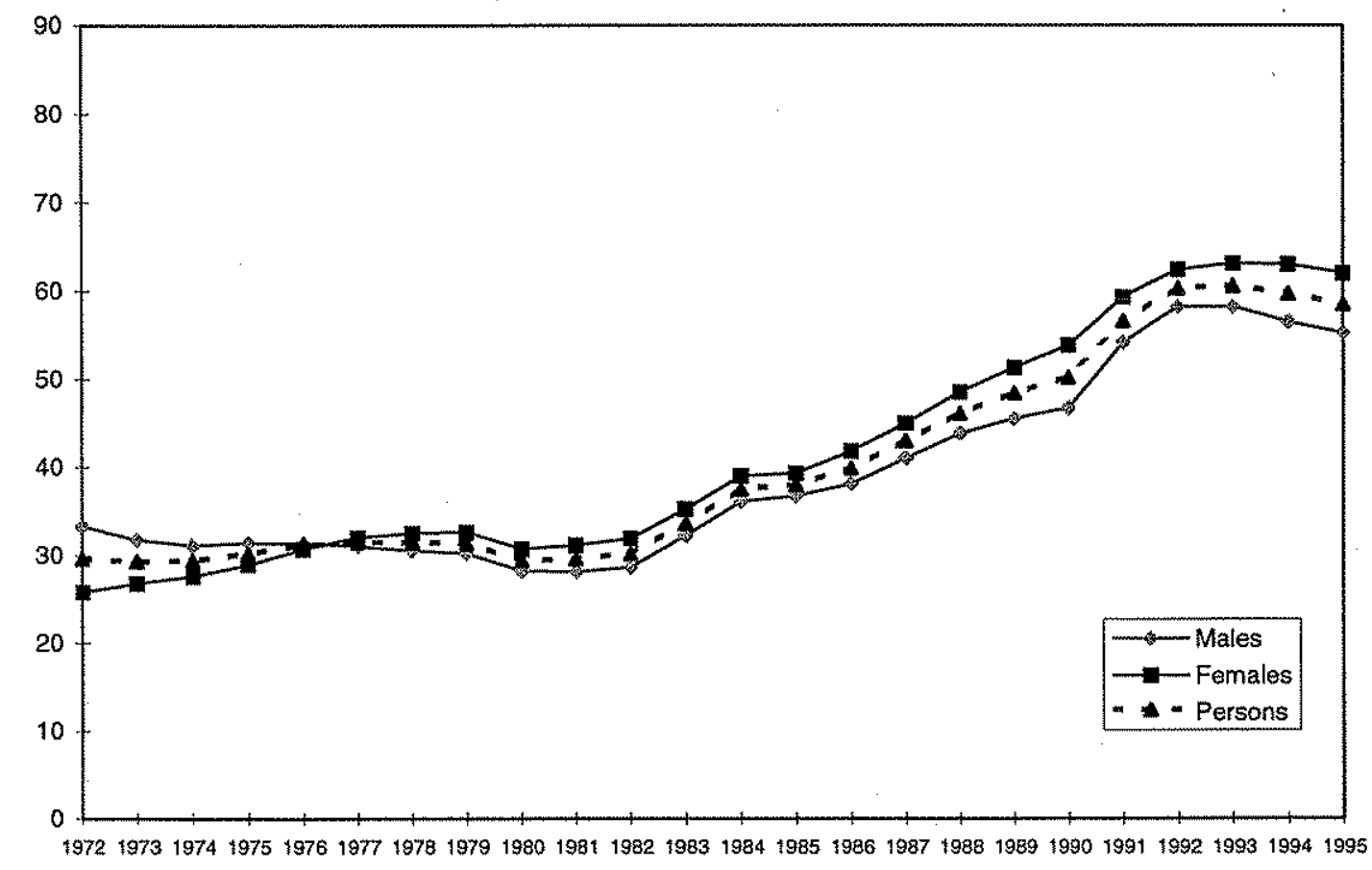

Source: Figures were derived from the Schools Australia Series, Cat. No. 4221.0, published by the Australian Bureau of Statistics. 


\section{STATE TRENDS}

Discussion of national trends in school retention conceals the fact that schools are divided along lines of state authority and are subject to differences in state economic conditions and in the composition and dispersion of domestic populations. The impact of these political and demographic differences is apparent in the rate of downturn in school retention since 1992, for the trend has not been communicated uniformly across all states. Figure 3 presents the falls in apparent retention rates by state. The fall in each case represents the difference between the highest rate of retention achieved (either 1992 or 1993) and the level recorded in 1995. While all states have recorded falls in apparent retention rates, the falls have been strongest in South Australia (23\% for males and $20 \%$ for females), Queensland (11\% for males and $8 \%$ for females) and the Northern Territory (14\% for males and $15 \%$ for females). New South Wales, Tasmania and Western Australia recorded much smaller declines.

It is important to note that the comparisons using ABS figures are not adjusted for differences in levels of grade repeating and migration. These have had a major influence on the figures for South Australia and the Northern Territory where changes to certification requirements increased rates of grade repeating during the late 1980s and early 1990s. This resulted in inflated retention rates until 1992 and dramatic falls since then. A national report on repeating Year 12 students also found that Queensland experienced a decline in the level of grade repeating from 1991 to 1994 (Department of Employment, Education and Training, 1995). This contributed to a larger fall in the retention rate.

Yet despite these limitations, state comparisons are still of value and can be revealing because long term patterns of growth or decline occur within the contexts of state provision. Differences across states in economic conditions, in labour market opportunities, in senior school programme development, in institutional reforms, as well as in populations can affect the rates at which opportunities in senior school are taken up. Figure 4 presents state-level retention rates for the period from 1980 to 1995. During the period of dramatic expansion in school completion in the 1980s, some states achieved much stronger rates of growth than others. The states which began the 1980s with the weakest levels of retention, Tasmania and New South Wales, experienced weaker rates of growth compared to other states. This widened the gaps over the decade. For the two largest systems (Victoria and New South Wales), for example, there was only a 1 percentage point gap in the rate of retention for males in 1980. By 1991 this gap had increased to 12 percentage points. Differences between states grew until the late 1980s when the gaps began to narrow as retention rates neared their peaks in the early 1990s. The differential downturn in rates of retention since 1992 has led to convergence across the states in rates of school completion, returning to the patterns of the early 1980s. This is in part because the states displaying the most rapid growth during the 1980 s have also recorded the largest falls in recent years.

\section{SECTOR TRENDS}

In all states retention rates to Year 12 have fallen over the last few years. Comparison of sectors shows how the trends are distributed and thus affords some insight into their origins. Figure 5 and Figure 6 present the falls in retention by sector and state. The graph shows that the decline in state retention rates has had its main source in the government sector. For males, the government sector in every state recorded a consistent fall in retention. The largest declines were experienced in Victoria, Queensland and South Australia and the smallest in New South Wales and Tasmania. For females there is a similar pattern except for New South Wales where the rate continued to grow rather than fall over the period. 
FIGURE 3: Fall in apparent school retention by state Males

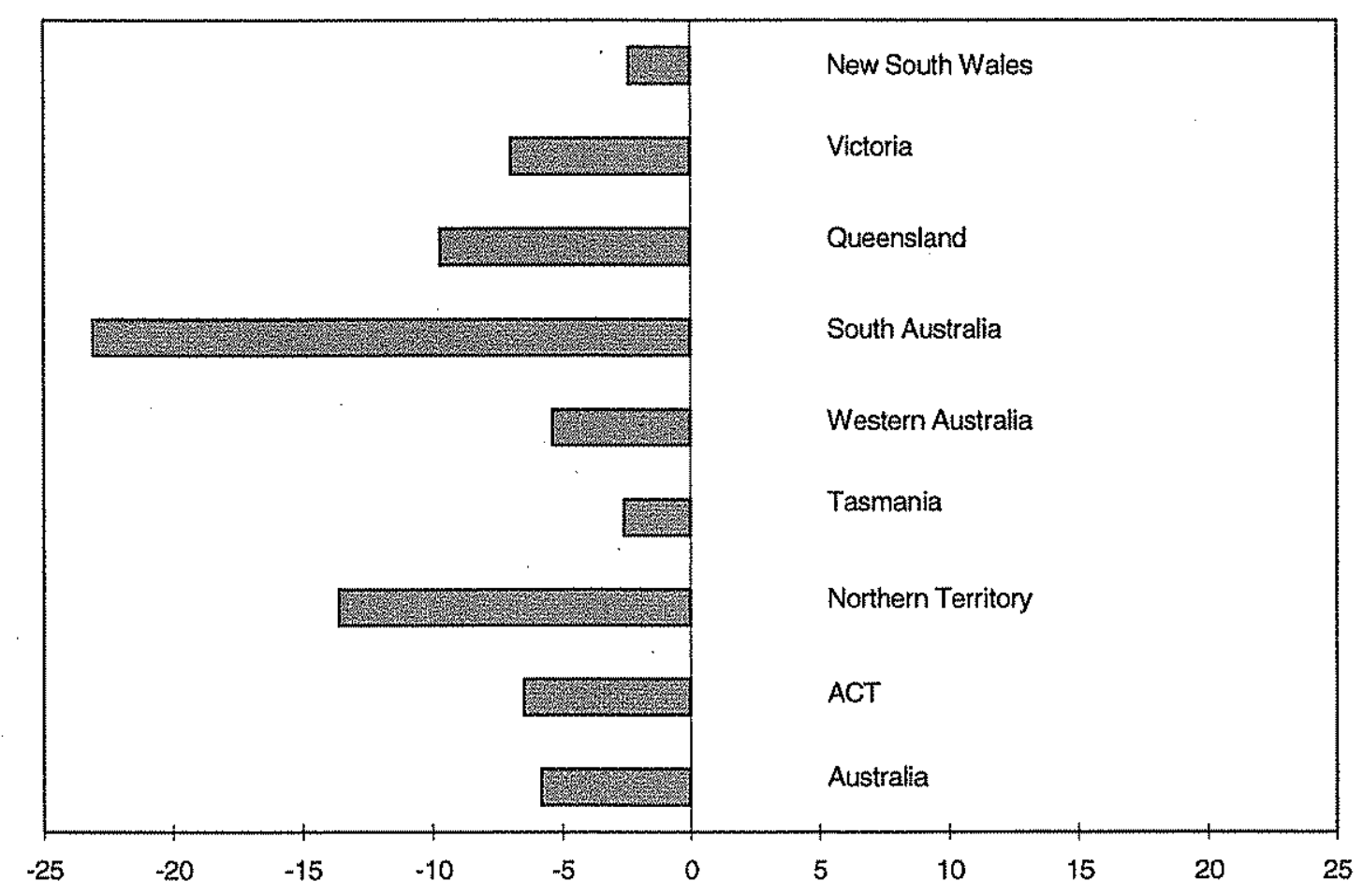

Females

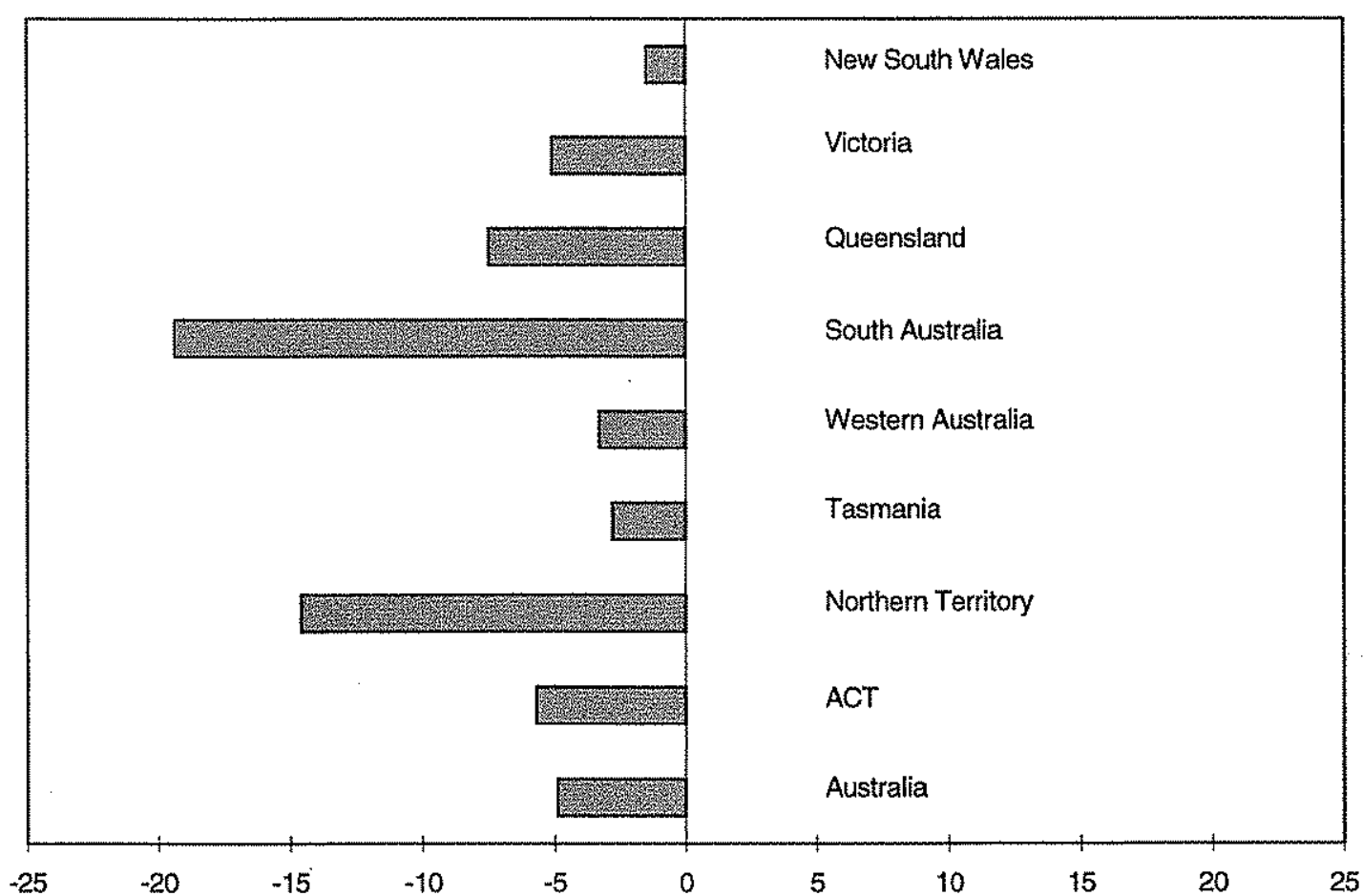

Source: Figures were derived from the Schools Australia Series, Cat. No. 4221.0, published by the Australian Bureau of Statistics. 
FIGURE 4: Apparent retention rates by state, 1980 to 1995

\section{Males}

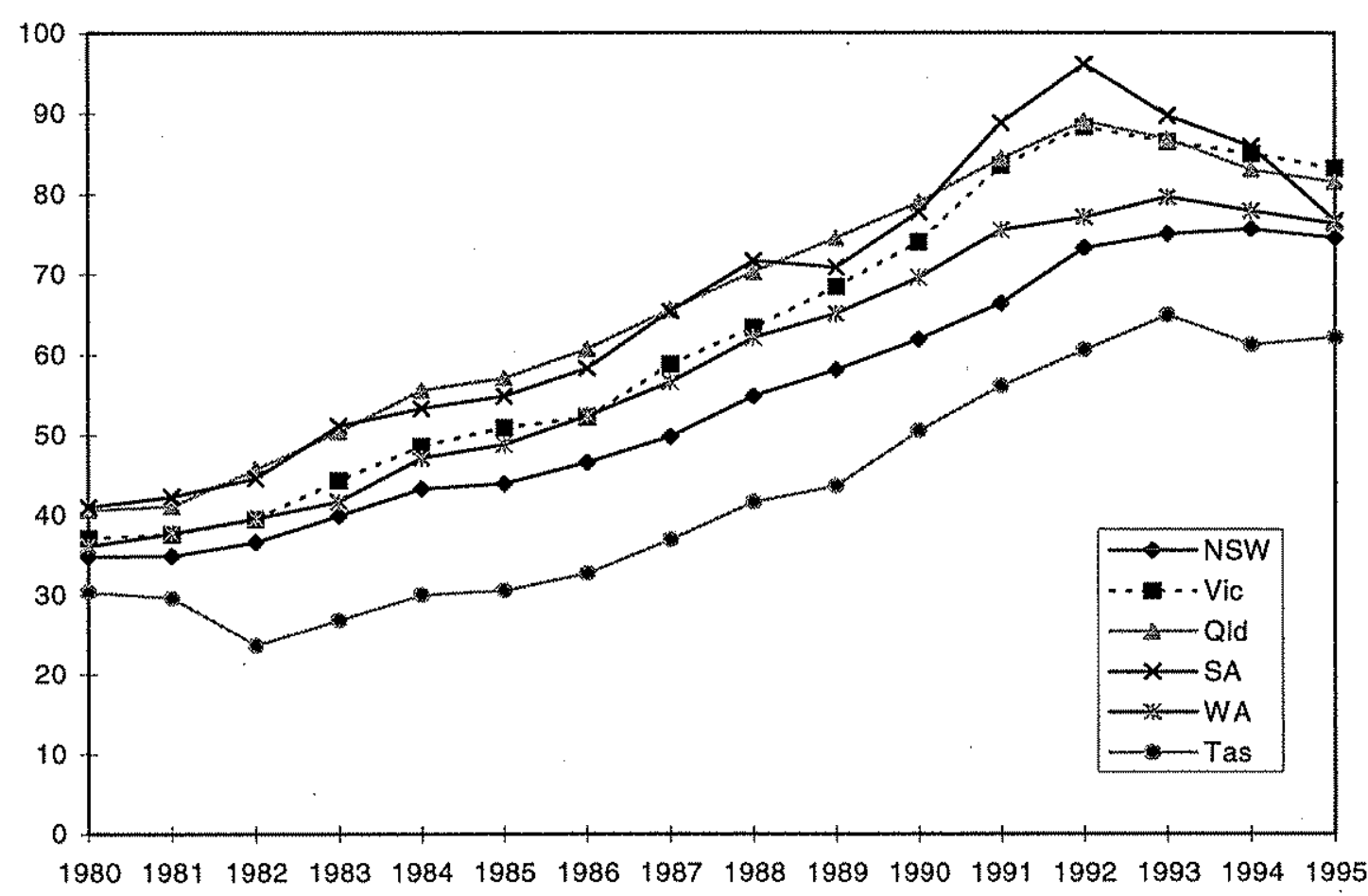

Females

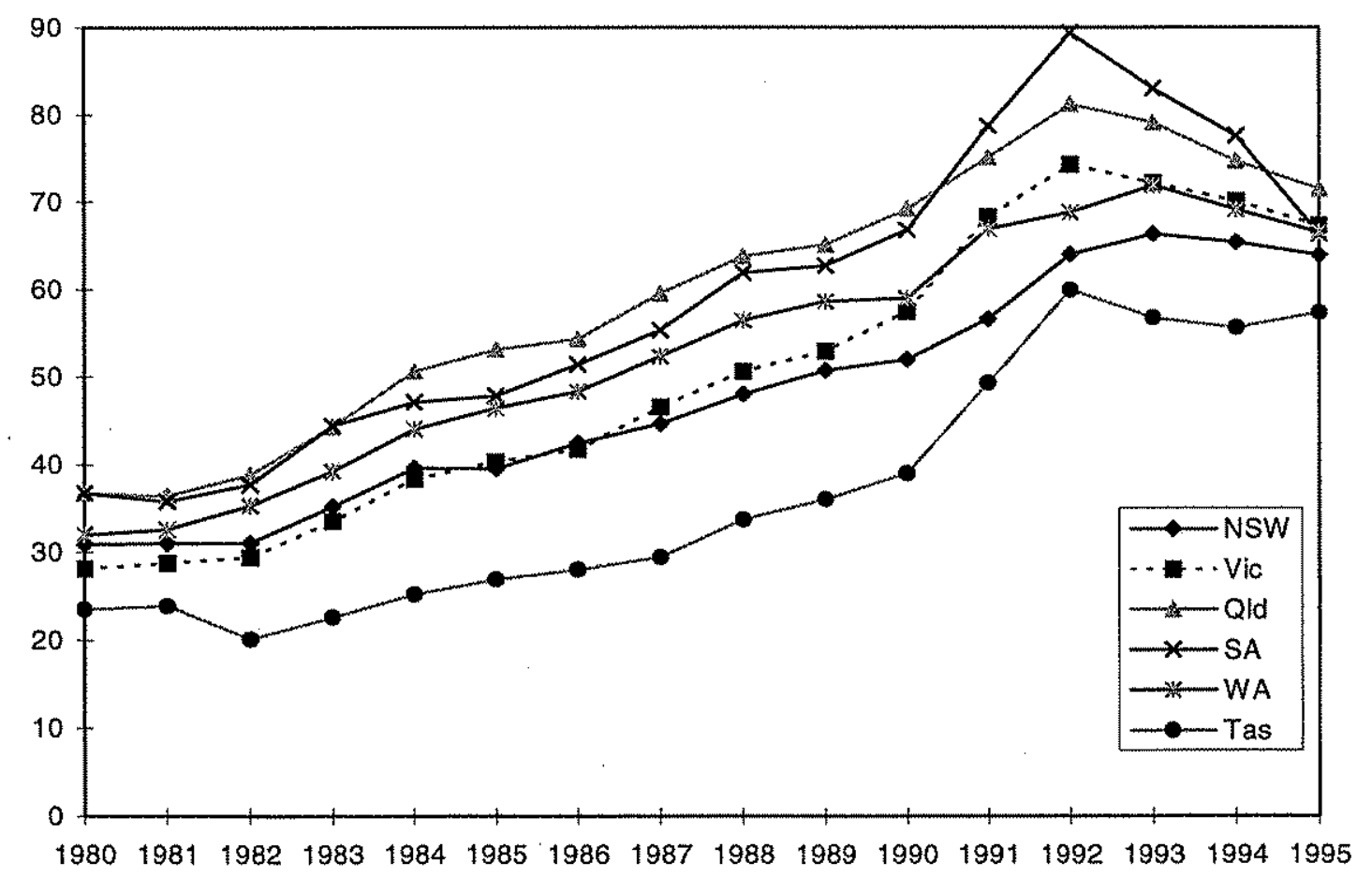

Source: Figures were derived from the Schools Australia Series, Cat. No. 4221.0, published by the Australian Bureau of Statistics. 
Declines in retention rates in Catholic schools have been weaker and less consistent. In each state the declines have been much lower than for the equivalent government sectors. Indeed for males, New South Wales recorded marginal growth rather than decline while the noticeably lower falls in other states suggest that Catholic schools have been more immune to the recent pressures promoting a move away from school. The same is true for females where both New South Wales and Queensland experienced increases in retention in recent years and losses were small in other states (apart from South Australia where a drop in grade repeating since 1992 has accentuated decline in all three sectors).

The figures for private non-Catholic schools are more difficult to interpret. This is partly because retention rates are not a good measure of comparative performance for this sector as we shall see. Taking the rates for females, on the surface it would appear that substantial falls have been recorded in the independent sectors in New South Wales, Western Australia, Victoria, Queensland and South Australia -- falls equal to or larger than in government and Catholic schools. These suggest that private schools have been a source of decline in rates of recruitment to Year 12. However, the downturn in retention rates are not the product of a sudden reversal in holding power on the part of private schools. On the contrary, recent years have been a period of continued expansion and further consolidation of their long term patterns of strong enrolments. The recent trends in retention have been influenced by a shift in the year levels at which there has been growth in recruitment. This is apparent from a comparison of Year 7 and Year 11 enrolments. The national figures are displayed in Figure 7.

Thanks to the effects of enrolment drift after the initial point of entry to secondary school, Year 11 female enrolments have been well above the enrolment levels for the base year (Year 7) four years earlier. The number of Year 11 girls in 1989 was 1300 more than the enrolments in Year 7 four years earlier. Since 1989, however, the gap has begun to decline as Year 7 recruitment outstripped growth at Year 11. Similarly for boys, Year 11 recruitment grew marginally from 1990 to 1995 while the Year 7 enrolments for the base period (1985-1991) continued to rise more quickly. These changes reflect a shift in the points of growth in nonCatholic private schools with expansion being stronger at or before rather than after the initial point of entry to secondary school. The upshot of the changes in points of recruitment (and in "enrolment drift") has been to produce a decline in patterns of retention in recent years. In effect the stronger growth in the junior levels has weakened the inflationary impact on school retention rates of post-Year 7 enrolment drift. This means that the recent decline in retention calculated for private schools has been more artificial than real. ${ }^{1}$

The results show that the source of the recent downturn in school retention has been in government schools. Figure 8 presents the trends at a national level from 1980 to 1995 . Government schools in Australia began the 1980s with a low base of retention: $25 \%$ for males and $35 \%$ for females. Even so, it was this sector that experienced the most rapid growth across the decade, closing the gap with Catholic schools. By 1992 for males less than 5 percentage points separated Government and Catholic schools, compared to 20 percentage points a decade earlier. The rates for females, where the differences were smaller at the beginning of the period, by 1992 had actually converged $(79.0 \%$ in Government schools and $79.6 \%$ in Catholic schools). Since that time retention rates for the government sector have declined causing the gap to increase once again. It would appear that the populations which had the most ground to make up and historically had made the least use of extended schooling have been the most vulnerable to the recent pressures influencing the move away from school. 
FIGURE 5: Fall in apparent retention rates for males by state and sector

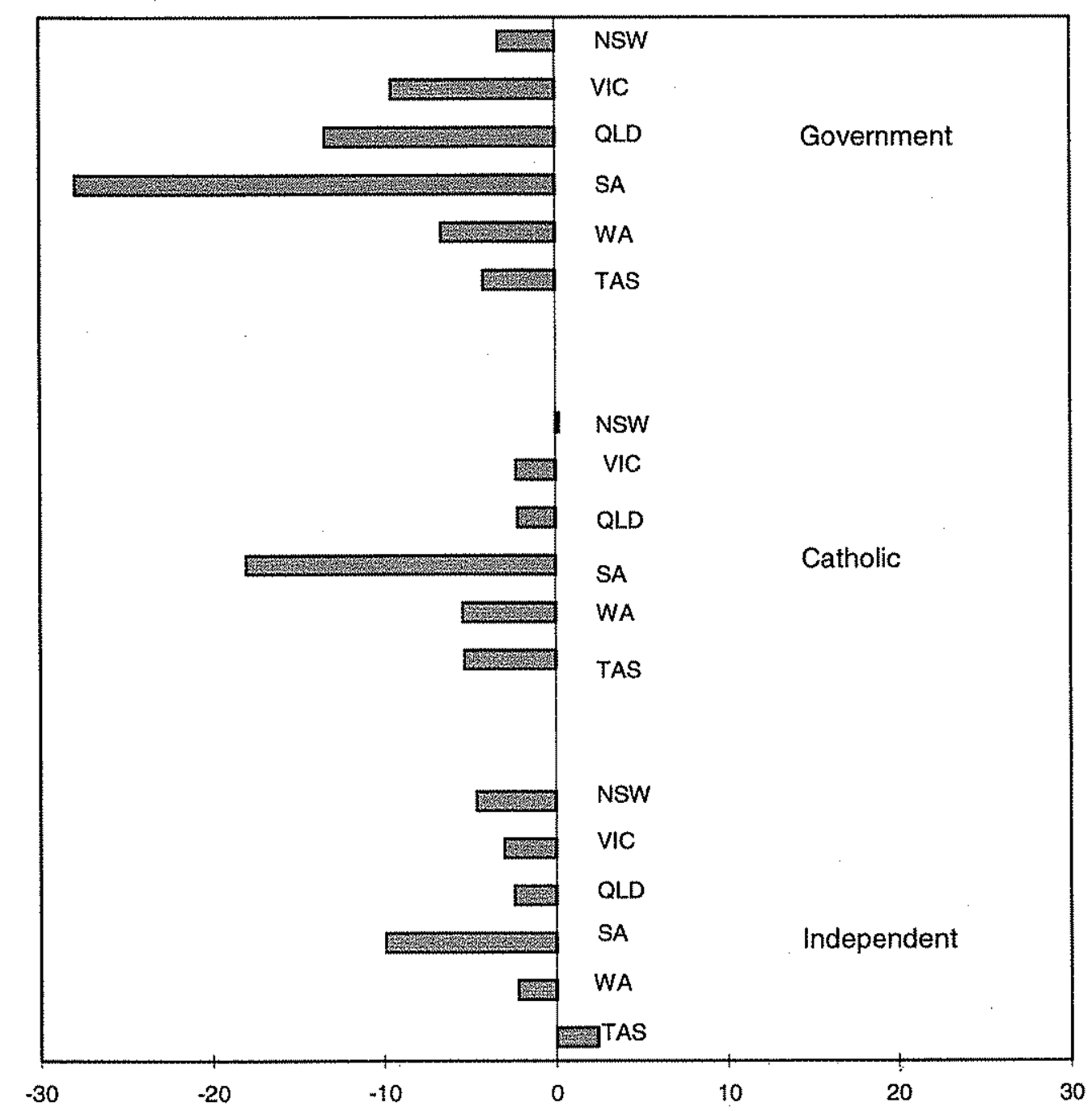

Source: Figures were derived from the Schools Australia Series, Cat. No. 4221.0, published by the Australian Bureau of Statistics. 
FIGURE 6: Fall in apparent retention for females by state and sector

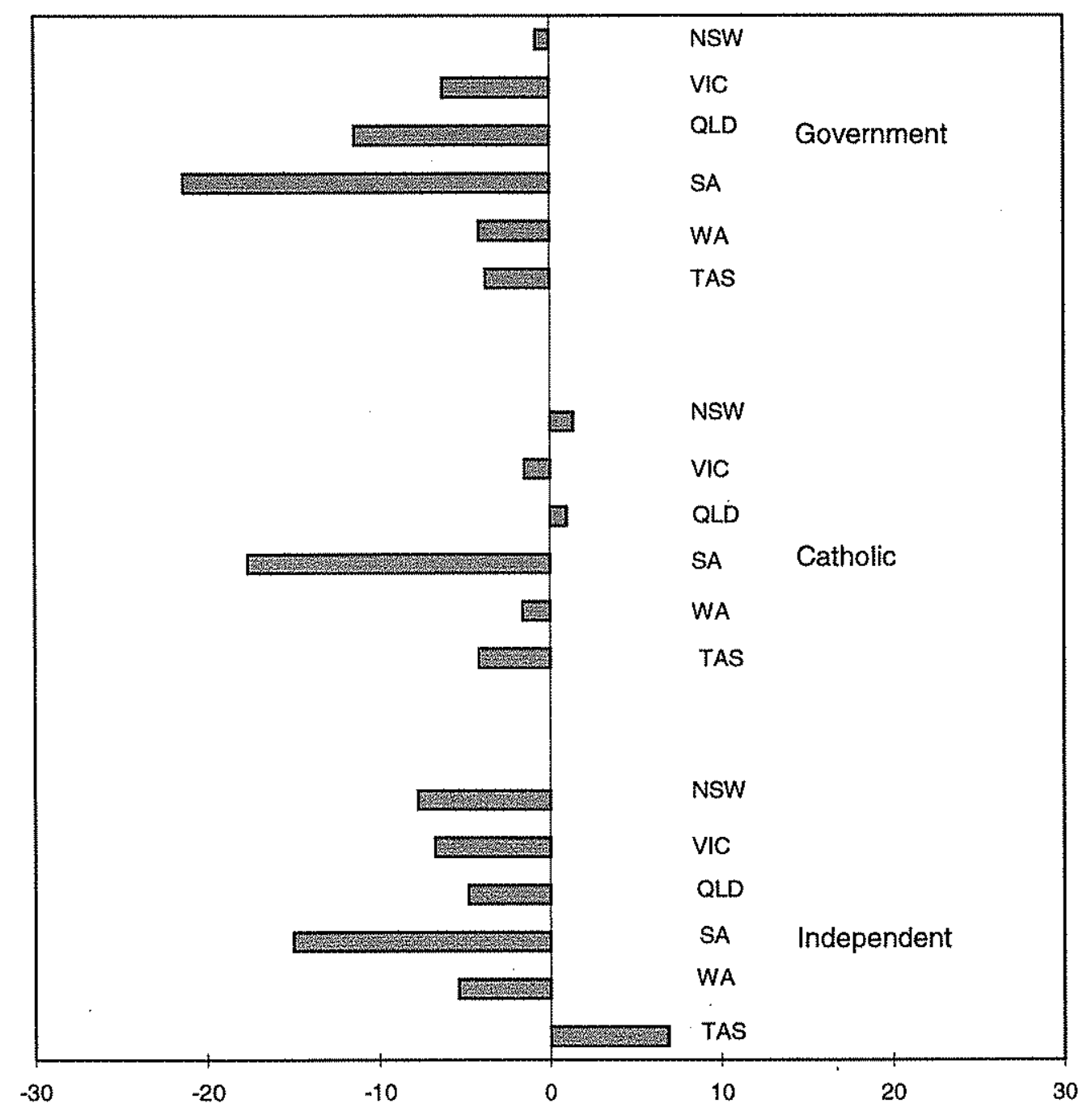

Source: Figures were derived from the Schools Australla Series, Cat. No. 4221.0, published by the Australian Bureau of Statistics. 
FIGURE 7: Growth of Year 7 enrolments and Year 11 enrolments four years later: non-Catholic private schools, Australia

\section{Males}

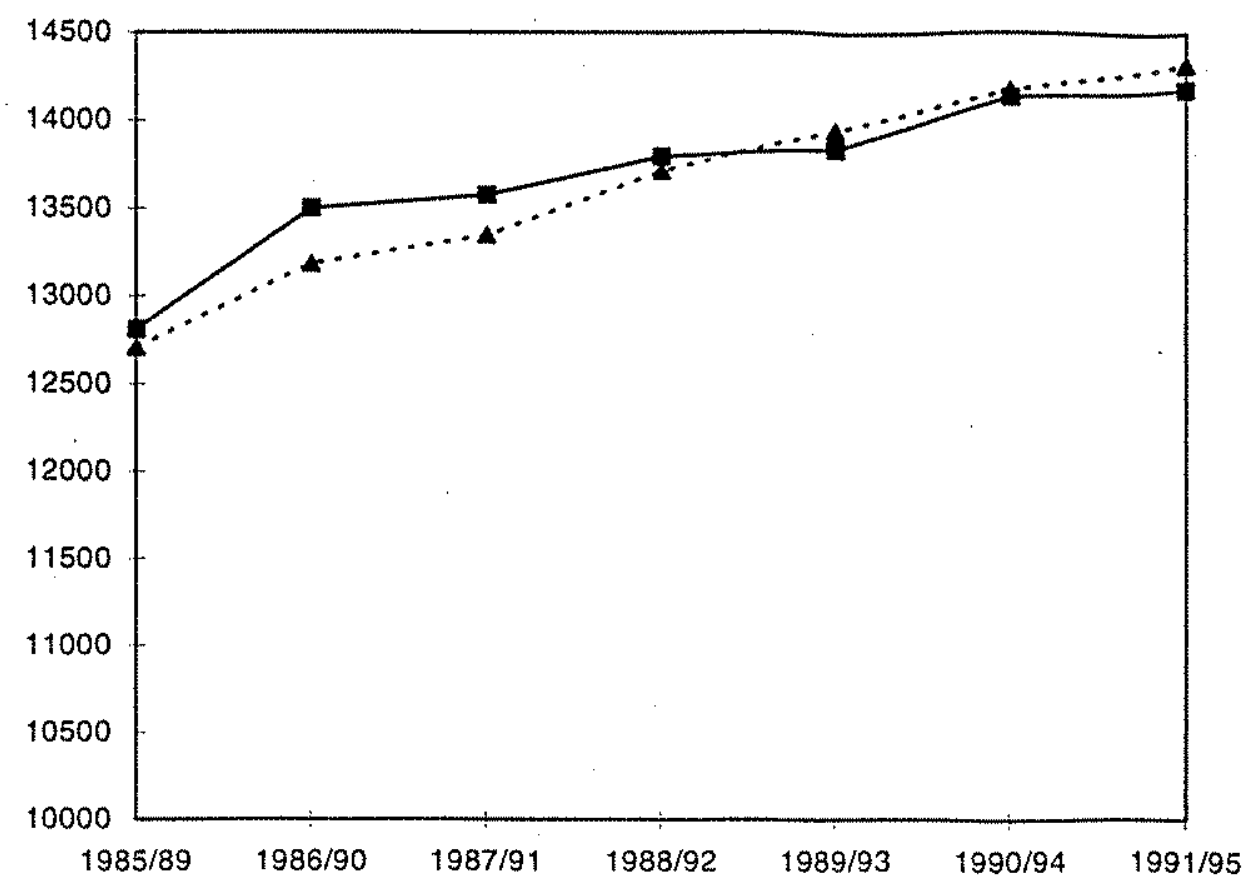

Females

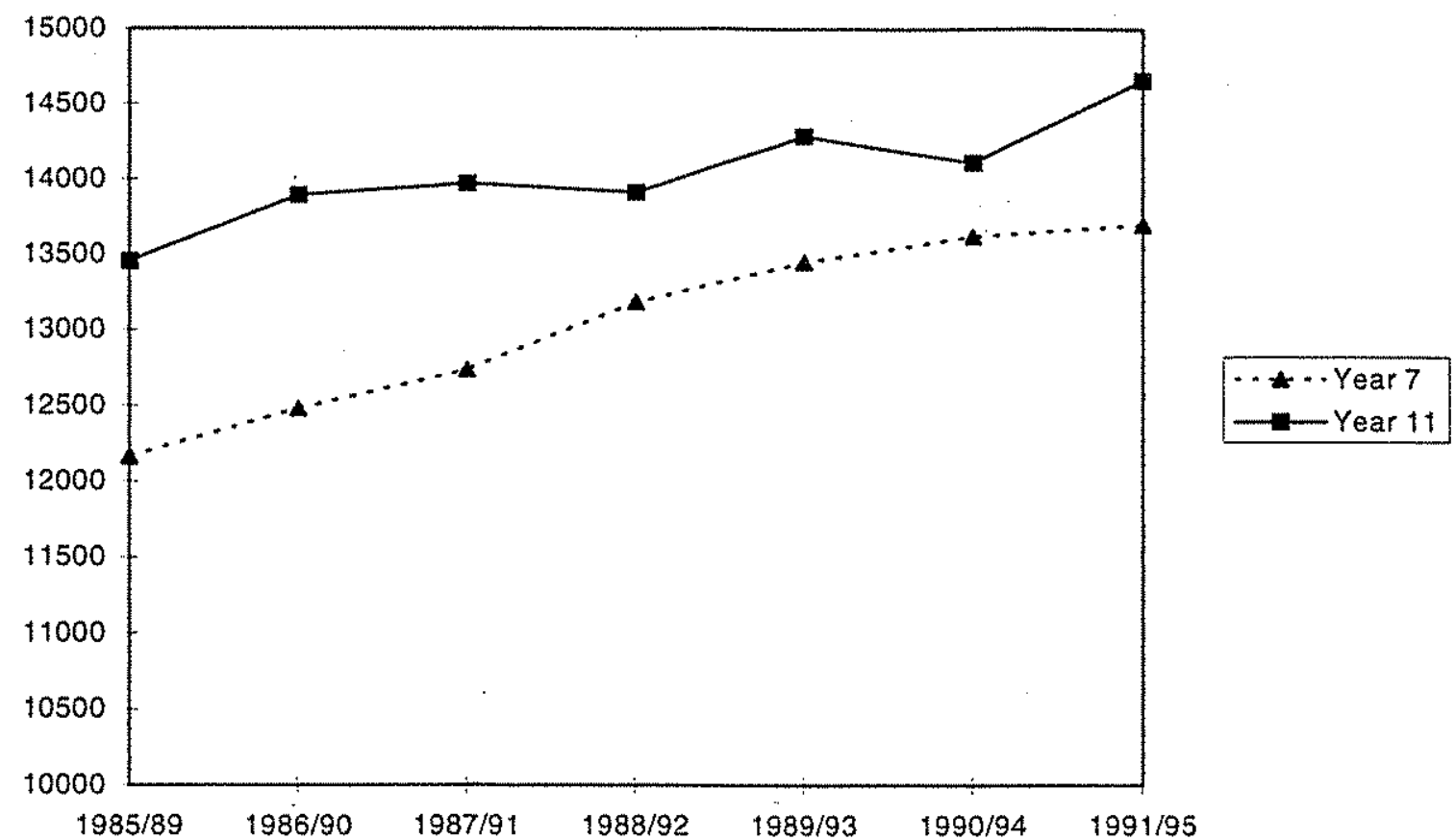

Source: Figures were derived from the Schools Australia Series, Cat. No. 4221.0, published by the Australian Bureau of Statistics. 
FIGURE 8: Apparent retention rates by sector, Australia, 1980 to 1995

\section{Males}

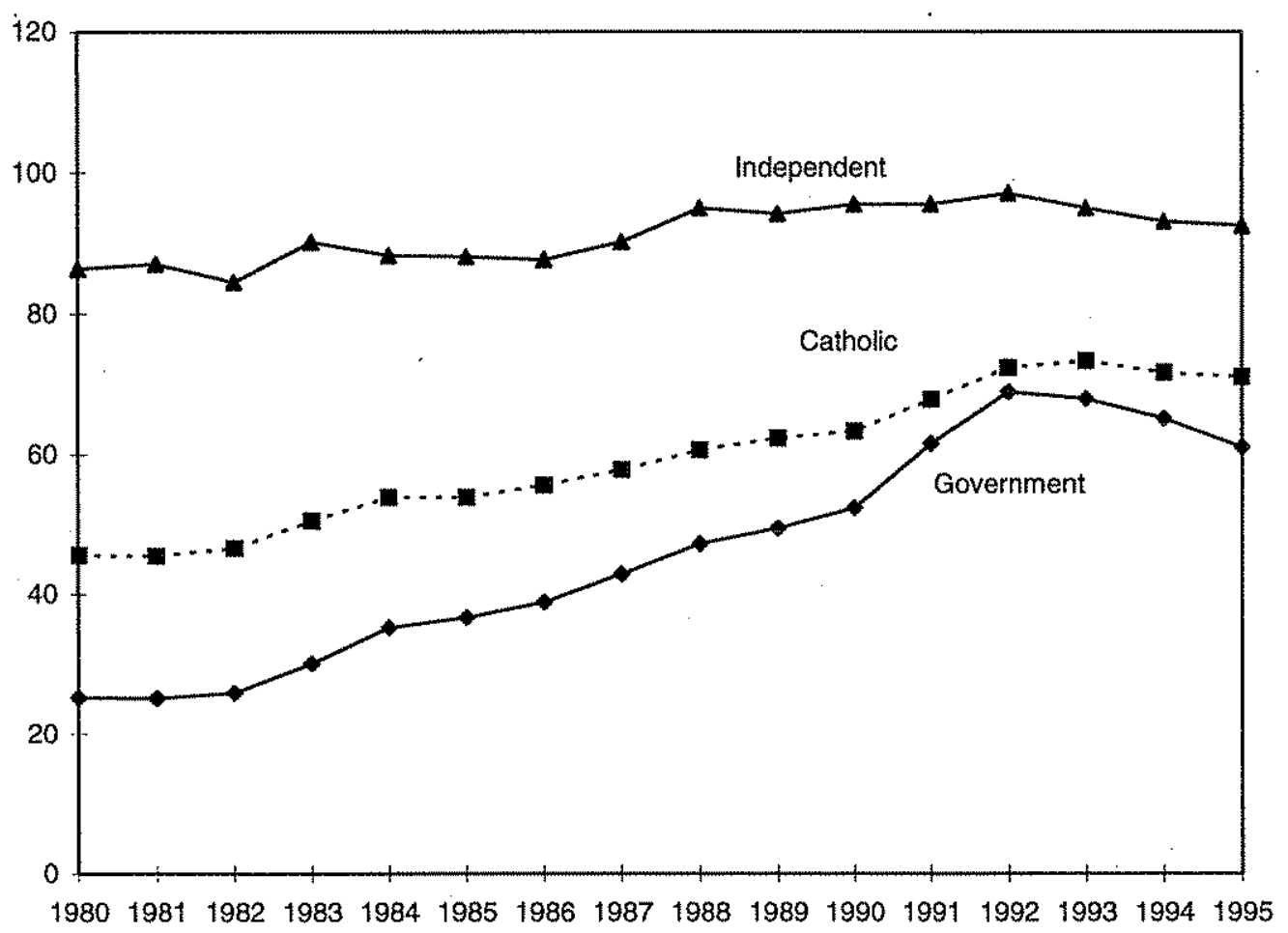

\section{Females}

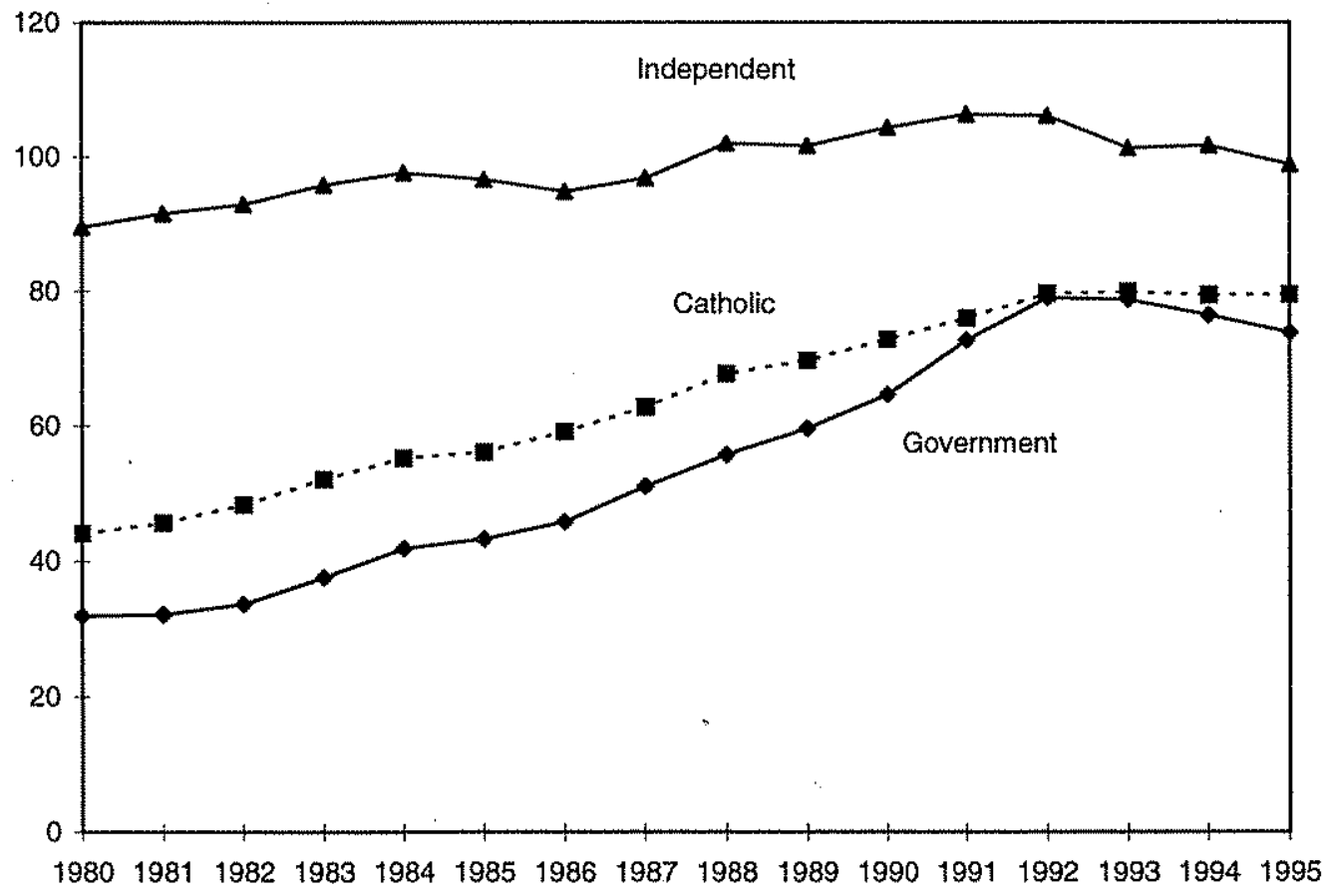

Source: Figures were derived from the Schools Australia Series, Cat. No. 4221.0, published by the Australian Bureau of Statistics. 


\section{SOCIAL TRENDS}

So far the analysis has been based on ABS data which are derived usually from an annual school census in each state and territory. Aggregate figures of this kind are useful for making state- or system-level comparisons. However they are less useful for looking at social and geographic patterns. Has the recent downturn in school retention affected children more in rural than in urban areas? What about for children from different family backgrounds? What are the social origins of the move away from school? In this section, we will attempt to describe the social distribution of the decline in school completion which has taken place in Australia by making use of data from a national longitudinal study, the Australian Youth Survey (AYS).

AYS began in 1989 with a nationally representative sample of 5,500 teenagers aged 16 to 19 . A new sample of 16 year olds was added each year from 1990 to 1994 . The main aim of the study is to monitor the experiences of young people as they make the transition from school to work. Information is collected annually on school, post-school education and training, and work activities. For the purposes of the present study the AYS data were used to construct annual samples of school leavers for the period from 1987 to 1994 . Each sample comprised respondents who left school in that year, both Year 12 graduates and early school leavers. The samples cover the period immediately before and during the recent downturn in school completion, making it possible to examine changes in the composition of school completers over this period.

Respondents in each sample were identified as either Year 12 graduates, having completed Year 12, or early school leavers. Information on sample sizes, including the numbers of school completers, is presented in Table 1. Young people who completed Year 12 made up about $47 \%$ of the 1987 sample, $79 \%$ of the 1991 sample and $74 \%$ of the 1994 sample. The changes in proportions of school completers from 1987 to 1994 roughly match the national patterns in apparent retention rates. One point to note is that the downturn in school completion appears earlier than that recorded using the measure of apparent retention rates (1991 compared to 1993). This is because with retention rates there is a lag between the point at which early school leavers drop out of school (at the end of Year 10, Year 11 or earlier) and the point at which the rate of survival is measured, in this case to Year 12. The present study uses annual samples of school leavers and computes rates of school completion (and early school leaving) by computing the number of Year 12 leavers (and early school leavers) as a proportion of all school leavers for a given year. In this way early school leavers appear in the sample corresponding to the year that they left school. Consequently, a rise in early school leaving recorded using this method will appear prior to the corresponding downturn recorded in retention rates to Year 12.

Table 1 Sample sizes

\begin{tabular}{lllr}
\hline & Year 12 graduates & Early leavers & Total \\
\hline 1987 & $417(47.2)$ & $467(52.8)$ & 884 \\
1988 & $712(61.3)$ & $449(38.7)$ & 1161 \\
1989 & $937(64.9)$ & $507(35.1)$ & 1444 \\
1990 & $871(79.2)$ & $229(20.8)$ & 1100 \\
1991 & $836(78.7)$ & $226(21.3)$ & 1062 \\
1992 & $876(77.6)$ & $253(22.4)$ & 1129 \\
1993 & $854(76.0)$ & $269(24.0)$ & 1123 \\
1994 & $739(73.6)$ & $265(26.4)$ & 1004
\end{tabular}




\section{Rural and urban differences}

Rural and urban differences in school completion have been well documented in Australian research (DEET, 1987; Ainley, Batten and Miller, 1984b; Williams, 1987; Williams, Long, Carpenter and Hayden, 1993b; Teese, McLean and Polesel, 1992). Generally, across Australia, secondary school completion rates have been lower in rural areas than in metropolitan areas. ${ }^{2}$ For this reason the review of rural education undertaken in the early 1990s by the Australian National Board of Employment, Education and Training (NBEET) concluded that lower participation rates in senior secondary schooling were an indicator of disadvantage for children living in rural and remote areas of Australia (NBEET, 1991).

Results for the present study are presented in Figure 9. They show that nationally in the late 1980 s there was roughly a 10 percentage point gap between the Year 12 completion rates of urban and rural students. Across the seven years to 1994, the gap for females remained essentially unchanged. In 1993, for example, where $75 \%$ of female school leavers in rural areas completed Year 12, the comparable figure for urban students is $84 \%$. From 1990 the downturn in proportions of school completers did not change the relative differences between girls living in rural compared to urban areas. It would seem that the trend away from school involved both rural and urban females.

The same is not true for males. In the late 1980 s there was a similar pattern of growth in school completion for both rural and urban students with the gap between rural and urban males remaining relatively unchanged. However the peak in Year 12 completion occurred for urban students in 1990 while the rate for rural students continued to rise reaching its height the following year in 1991. Because of this, rates of school completion for urban and rural students converged in 1991. Since that time the rate of school completion has fallen more rapidly for rural students, so that by 1994 the gap between urban and rural students was the same as in the late 1980s. The difference in rate of downturn suggests that the recent decline in school completion has been greater for boys in rural areas than for those living in the city.

\section{Language background differences}

School completion rates have in the past been stronger for children from non-Englishspeaking backgrounds. There is consistent evidence from the early 1980s that young people of non-English-speaking background have higher rates of participation in post-compulsory schooling and greater likelihood of completing school (Williams, Long, Carpenter and Hayden, 1993a; Ainley, Batten and Miller, 1984b; Miller and Volker, 1989). The present findings are consistent with this trend. Figure 10 compares rates of school completion for children from English-speaking and non-English-speaking backgrounds. Non-Englishspeaking background refers to persons in our samples with mothers born outside Australia in a non-English-speaking nation. English-speaking refers to those with mothers born in Australia or in another English-speaking nation.

Nationally, across the nine years from 1987, the rates of school completion of students from non-English-speaking backgrounds show much the same pattern as those of Englishspeaking origins. The late 1980s was a period of substantial growth in rates of completion, followed by a period of slight decay. Differences between those of English-speaking and those of non-English-speaking origins changed little over the time suggesting that the recent downturn in school completion has involved both groups of students. 
FIGURE 9: School completion by rural or urban location,1987 to 1994

\section{Males}

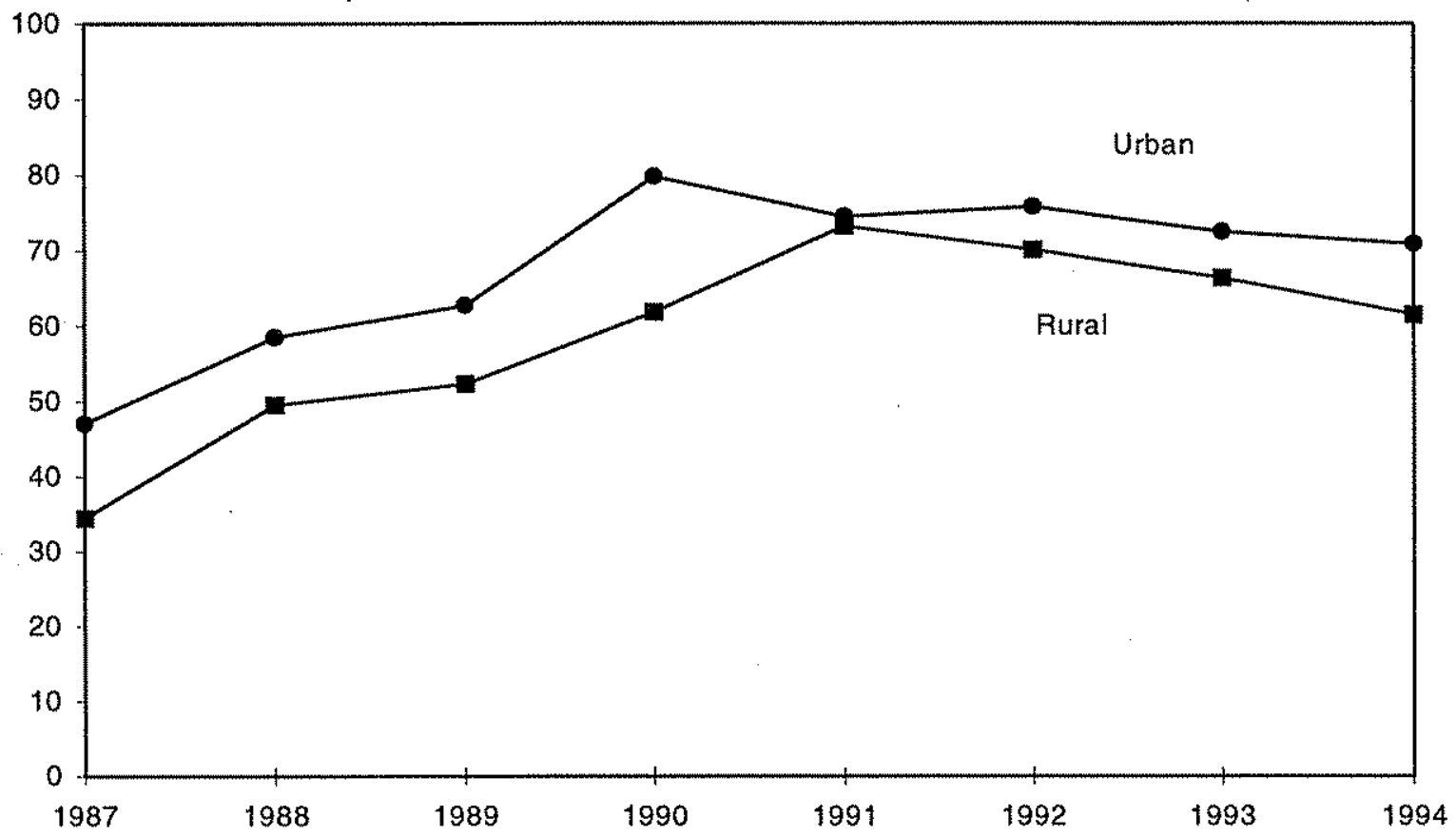

Females

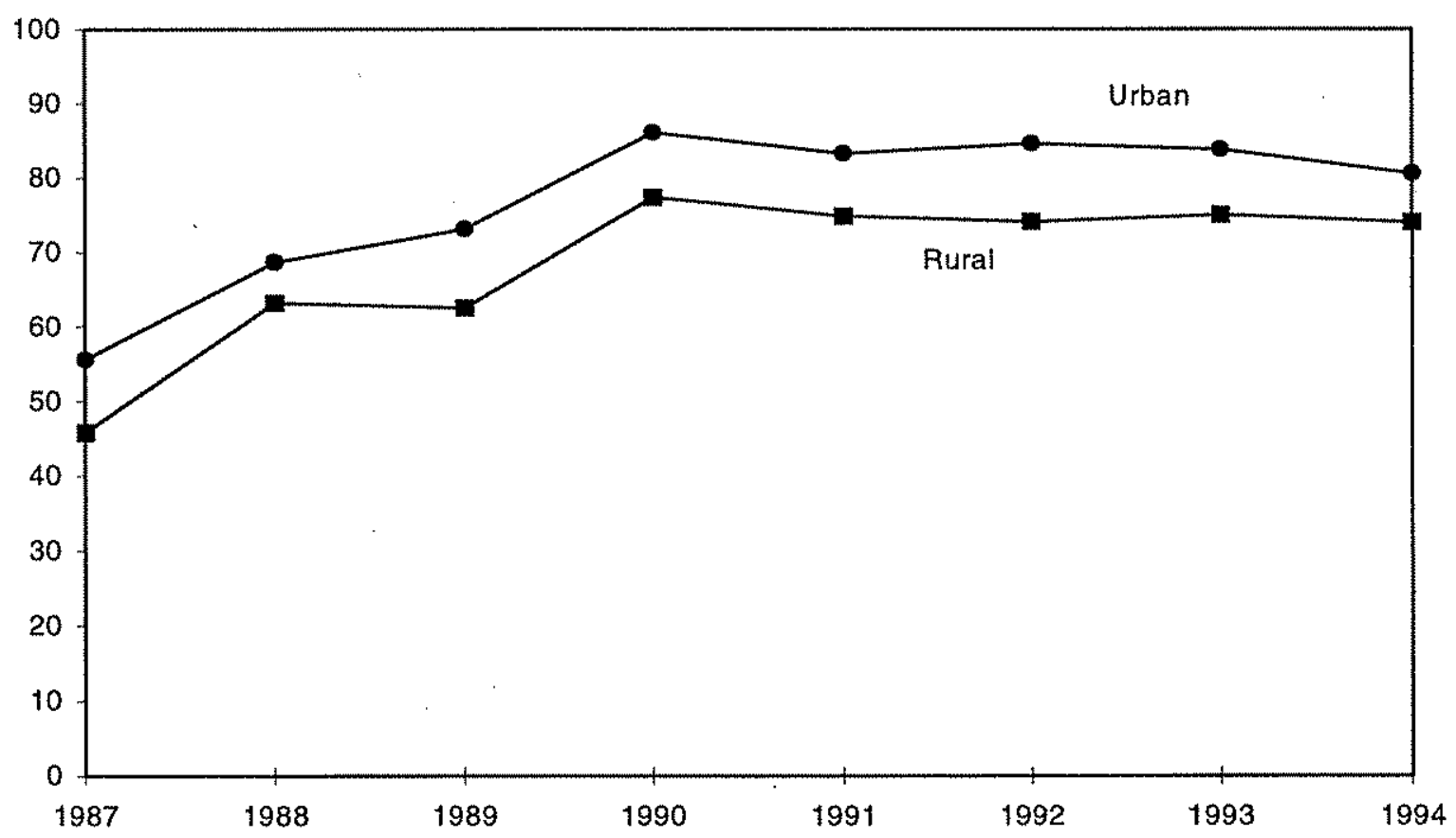

Source: Figures were derived from the Australian Youth Survey 
FIGURE 10: School completion by English-speaking background, 1987 to 1995

\section{Males}

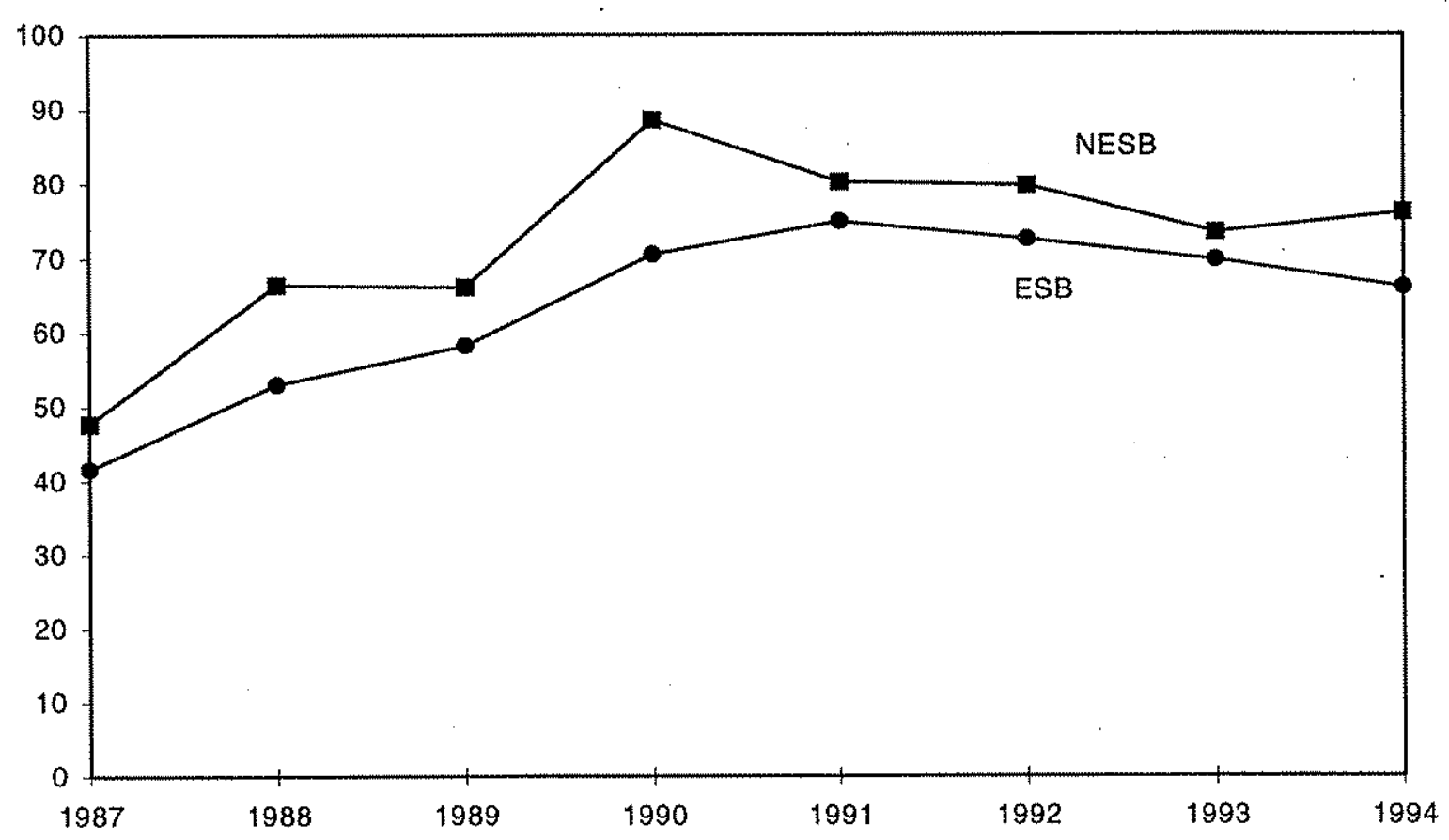

\section{Females}

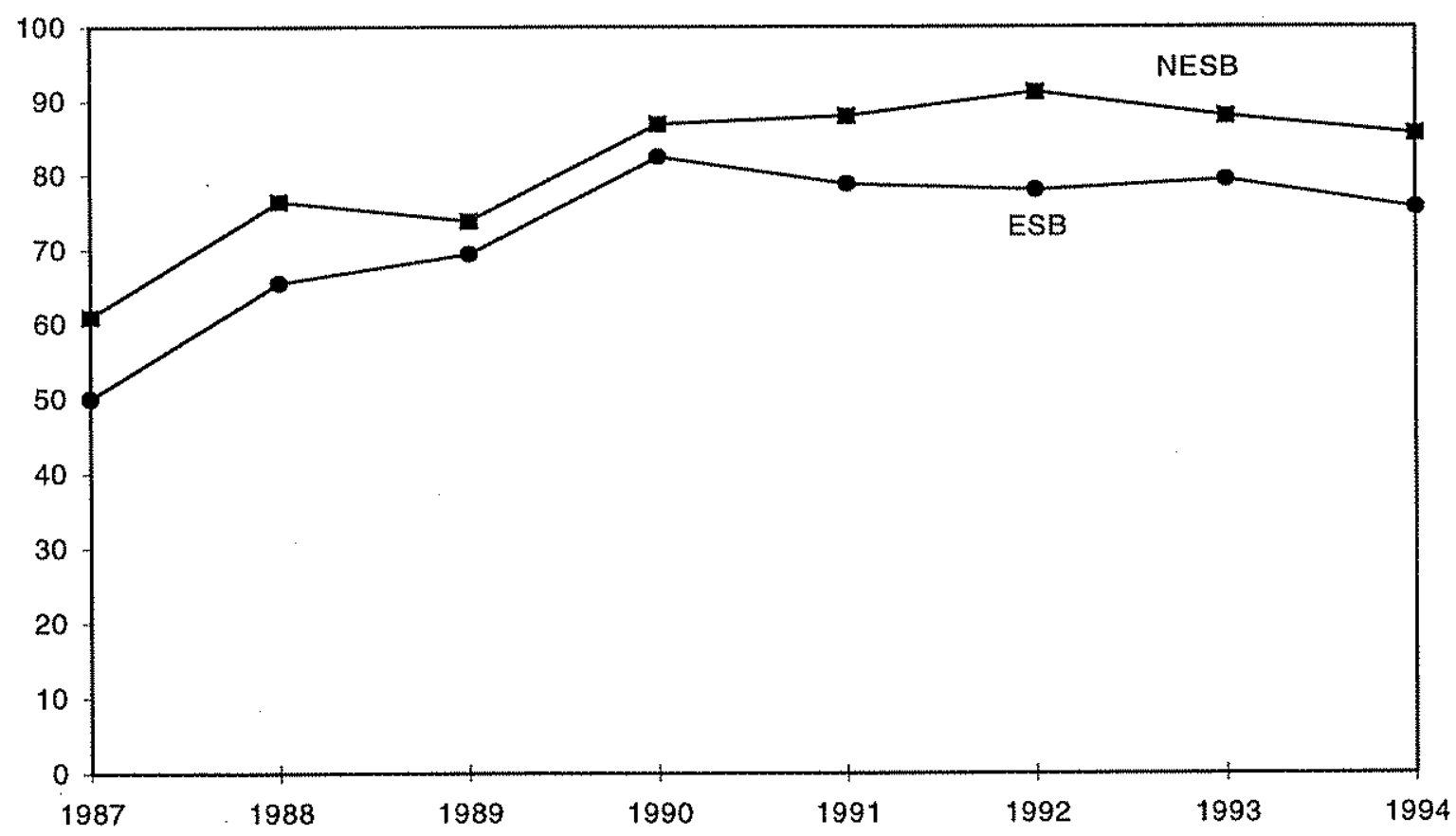

Source: Figures were derived from the Australian Youth Survey 


\section{Socioeconomic background differences}

Family socioeconomic status is an influential source of discrimination in school completion rates. Studies conducted using school level data by Power (1984) and Ainley, Batten and Miller (1984a, 1984b) have found that completion of school is more often associated with higher socioeconomic status: survival to Year 12 is much stronger in schools with high proportions of students from middle class origins. Studies reporting individual level data highlight the importance of family background: school completers more often come from families where the father has a professional or managerial occupation rather than a manual one, where the parents have more rather than less schooling, and where there is high family income (Australian Education Council, 1991; Williams, 1987; Miller and Volker, 1989; Williams, Long, Carpenter and Hayden, 1993). But as the results of this study show, the strength of the relationship between socioeconomic background and school completion has changed over the past decade. Figure 11 displays school completion rates for the decade prior to 1994 by father's occupation. Four occupational categories are used, following the status groupings proposed by Najman and Bampton (1991).

The period from 1987 to 1990 was marked by substantial growth in levels of school completion for all social groups. However, the strongest growth occurred among the groups with the lowest starting base, for those from unskilled manual and skilled manual origins. For both males and females this produced a narrowing in the gaps between social groups. For example, in 1987 a 35 percentage point gap separated boys from unskilled manual backgrounds and those from professional or managerial origins whereas in 1991 the difference was less than 18 points. But while this period saw a weakening of the social divide in school completion, the period since 1991 has seen a reversal of this trend, at least for boys.

Figure 12 displays the falls in school completion by occupational background. The falls are measured from the highest point of school completion reached in 1990 or 1991 and the rate recorded in 1994. While school during the 1980 s may have proved a source of security for a growing number of boys from unskilled manual backgrounds, it did not do so in the early 1990s. It is this group which has experienced the sharpest downturn in school completion since 1990, falling by over 13 percentage points. The smallest falls in school completion were experienced by boys from professional and managerial backgrounds ( 3 percentage points). The differences in rates of fall mean that the social gap in completion has increased during the early 1990 s.

In looking at the patterns for girls, it has to be kept in mind that the rates of school completion for girls as a group are substantially higher than for boys. This reflects, in part, differences in labour market opportunities available to young men and women. Girls have been more severely affected by the long term changes in Australian industry structure which has reduced work opportunities in areas traditionally pursued by early school leavers (such as in manufacturing). Largely excluded from the main single source of full time employment for young people -- apprenticeships -- and more at risk of unemployment, girls have been participating in post-compulsory schooling in greater numbers. Figure 12 shows that the falls in rates of completion have been more even for girls. Apart from the professional and managerial group, the fall in Year 12 completion was of a similar magnitude across groups: about 5 percentage points. The levels of decline for girls from skilled manual and clerical/ non-manual backgrounds matched those of their male counterparts. For girls from unskilled manual origins, the decline has been about one-third that of their male peers suggesting differences in the pressures, or responses to the pressures, to remain at school or leave. As they have done historically, students from professional and managerial backgrounds continue to make most use of school. 
FIGURE 11: School completion by father's occupation, 1987 to 1994

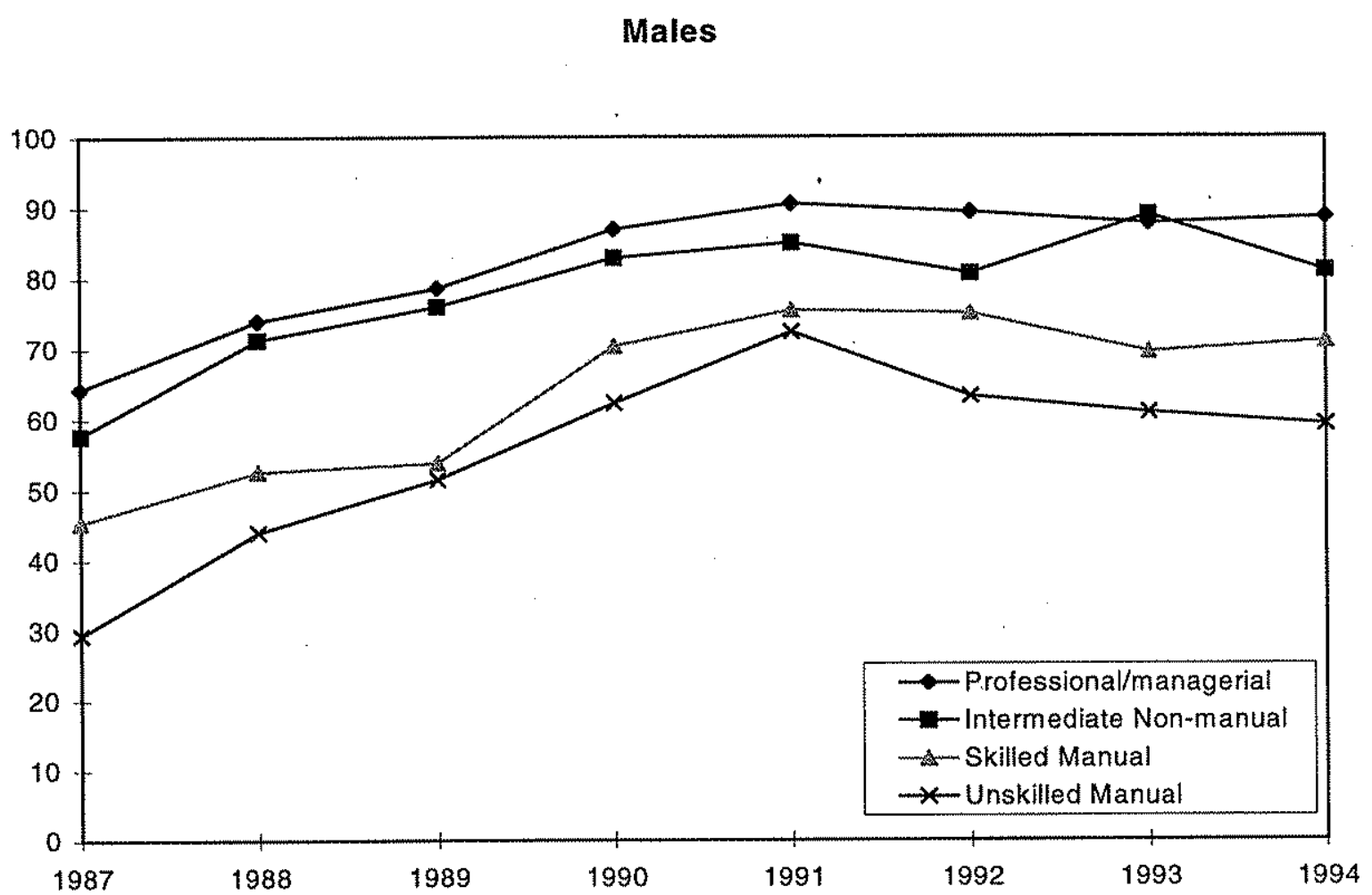

\section{Females}

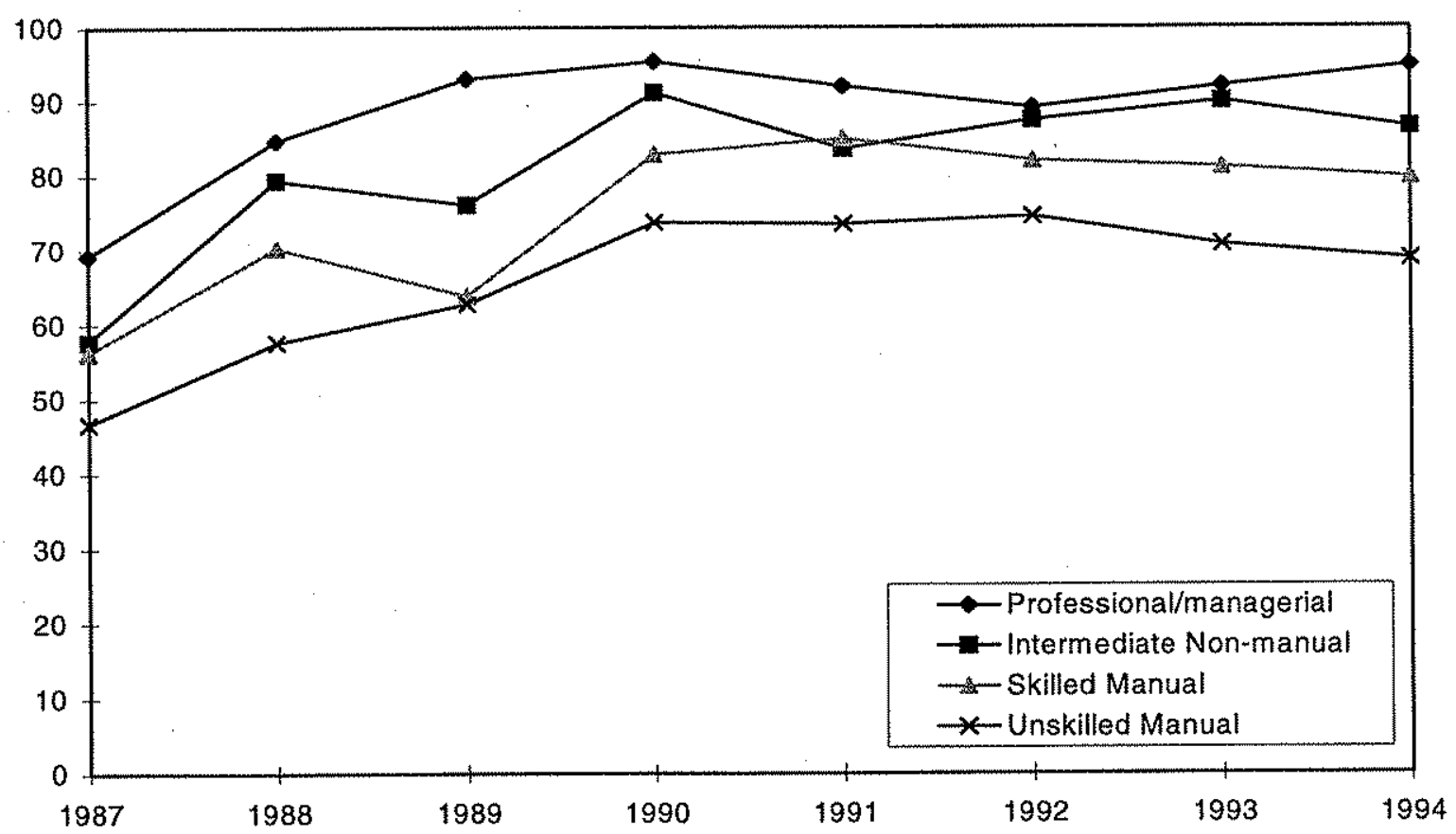

Source: Figures were derived from the Australian Youth Survey 
FIGURE 12: Fall in school completion rate by father's occupation

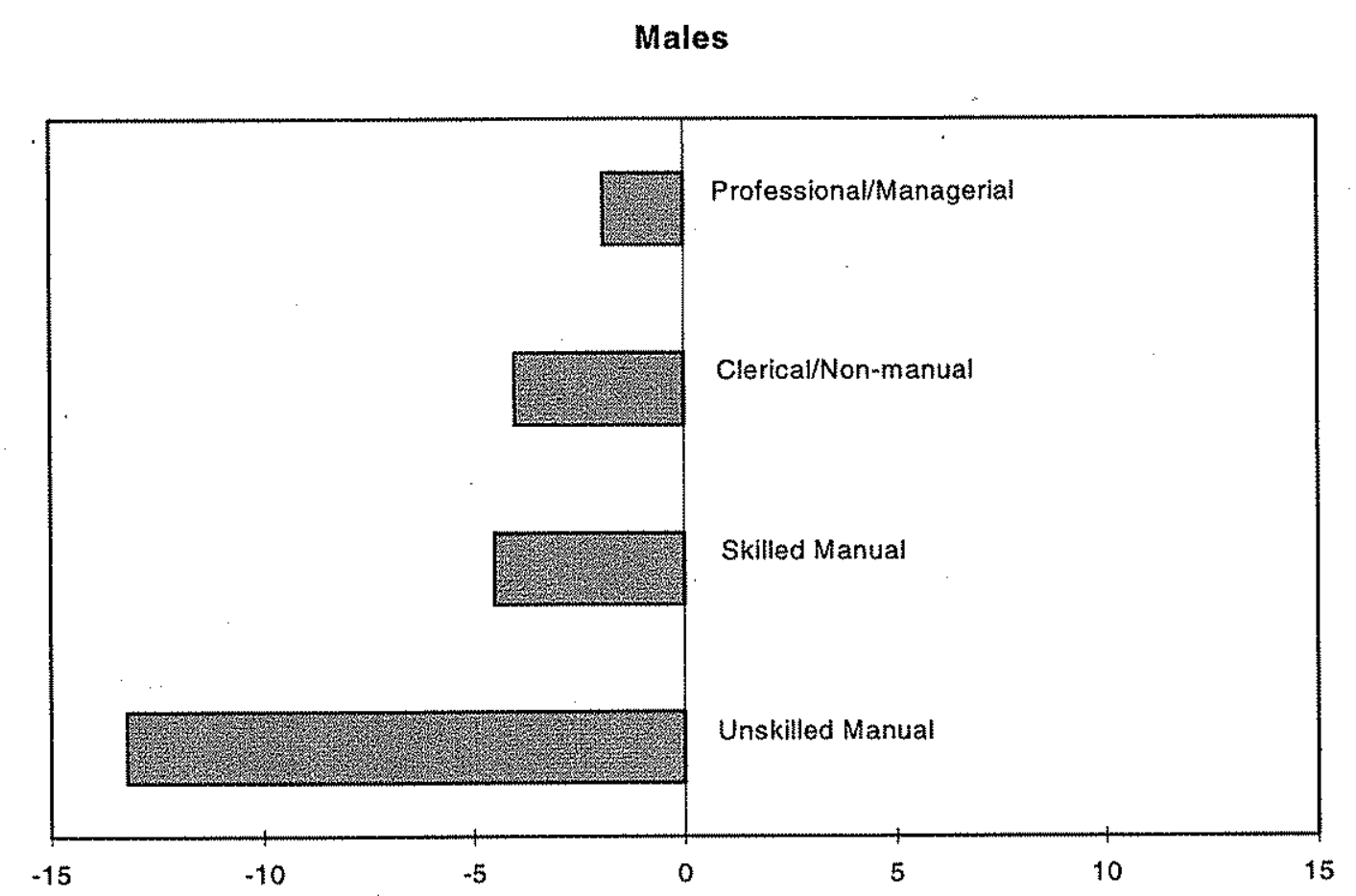

Females

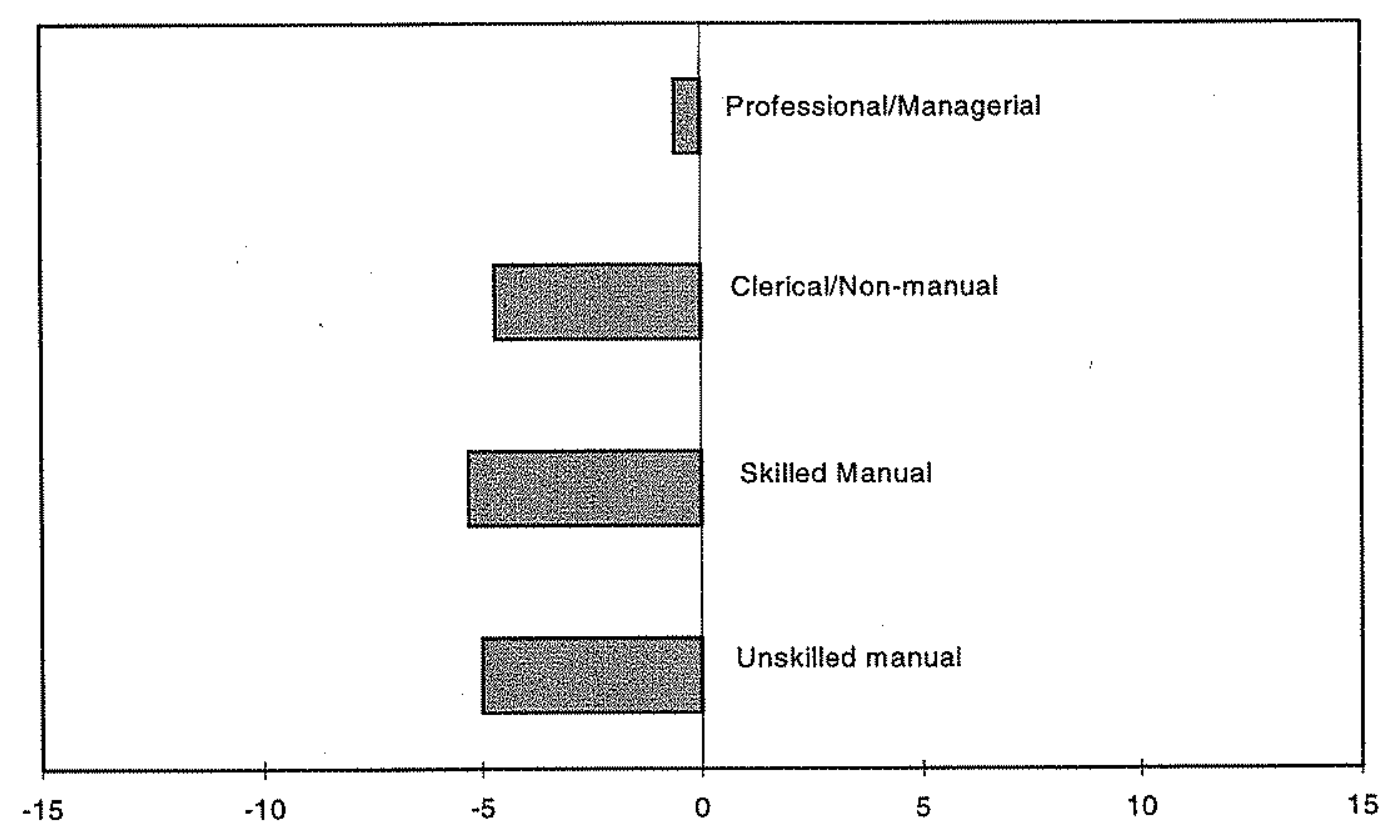

Source: Figures were derived from the Australian Youth Survey 


\section{Regression analysis}

In this section results are presented from logistic regression analyses which are used to look at changes in the relative influence of the different background factors across the period of decline in school completion. The analyses were conducted separately using three samples of school leavers: 1988, 1991 and 1994. The first sample, 1988, was chosen because it represents the period in which schools were still experiencing upward growth in school completion. The second sample, 1991, represents the point at which school completion rates had reached their peak, and the third sample is the most recent from the period of decline. Did the relative influence of the different background factors change across these years?

Several measures are used to examine the effects of social background on school completion. They are father's occupation, mother's education, rural or urban residence at age 14, and ethnicity (mother's country of birth). School type was included to measure the effects of sector. Descriptions of the measures are provided in Table 2. The analyses were conducted separately for males and females. The results are presented in Tables 3 and 4.

An important point to note with the results is the change in strength of effects at each year of measurement. In the year when schools were still expanding, 1988, father's occupation (skilled manual and unskilled manual), mother's education (university-qualified), ethnicity and school type (Catholic, non-Catholic private) were important determinants of school completion for boys. In 1991, when growth in school completion had reached its zenith and Year 12 participation become more universal, social differences had weakened to the point where father's occupation, mother's education and ethnicity were no longer statistically significant predictors of survival in school.

\section{Table 2 Description of Variables}

Variable

1. Year 12 completers

2. Father's occupation

3. Mother's Education

4. School type

5. Rural or urban

6. Ethnicity
The categories were coded as (1) school completers or (0) early school leavers.

The occupational status variable was separated into the following dummy variables: clerical/non-manual (1) or other (0); skilled manual $(1)$ or other $(0)$; and unskilled manual (1) or other $(0)$.

Three levels were used: university, other post-school training and secondary school participation or less. Two dummy variables were created based on university qualifications (1) or other $(0)$ and other postschool qualifications (1) or other (0).

Two dummy variables were created to measure the type of school attended. The first variable measured attendance at a Catholic school (1) or other $(0)$. The second variable measured attendance at a non-Catholic private school (1) or other $(0)$.

This variable covered young people residing at age 14 in (1) rural areas of Australia or (0) urban/metropolitan centres.

The birthplace variable, based on mother's country of birth, was coded as (1) born in a non-English-speaking nation or (0) other. 
Table 3 Logistic regression modelling school completion for 1988, 1991 and 1994: Males

\begin{tabular}{|c|c|c|c|}
\hline & 1988 & 1991 & 1994 \\
\hline Control male $^{a}$ & $\begin{array}{c}0.3588 \\
(0.3040)\end{array}$ & $\begin{array}{c}1.3124^{*} \\
(0.4171)\end{array}$ & $\begin{array}{c}1.8479^{*} \\
(0.4652)\end{array}$ \\
\hline \multicolumn{4}{|l|}{ Father's Occupation } \\
\hline Intermediate non-manual & $\begin{array}{l}-0.0073 \\
(0.3512)\end{array}$ & $\begin{array}{l}-0.2590 \\
(0.4747)\end{array}$ & $\begin{array}{l}-0.2455 \\
(0.5342)\end{array}$ \\
\hline Skilled Manual & $\begin{array}{l}-0.5680^{*} \\
(0.2210)\end{array}$ & $\begin{array}{l}-0.6918 \\
(0.4352)\end{array}$ & $\begin{array}{l}-1.0295^{*} \\
(0.4766)\end{array}$ \\
\hline Unskilled Manual & $\begin{array}{l}-0.9845^{*} \\
(0.3461)\end{array}$ & $\begin{array}{l}-0.7704 \\
(0.4518)\end{array}$ & $\begin{array}{c}-1.5217^{*} \\
(0.4899)\end{array}$ \\
\hline \multicolumn{4}{|l|}{ Mother's Education } \\
\hline University & $\begin{array}{r}1.4031^{*} \\
(0.4397)\end{array}$ & $\begin{array}{c}0.3943 \\
(0.5463)\end{array}$ & $\begin{array}{c}0.2130 \\
(0.3786)\end{array}$ \\
\hline Other Post-secondary & $\begin{array}{c}0.3135 \\
(0.2785)\end{array}$ & $\begin{array}{c}0.3529 \\
(0.3482)\end{array}$ & $\begin{array}{c}0.1813 \\
(0.3146)\end{array}$ \\
\hline \multicolumn{4}{|l|}{ School Type } \\
\hline Catholic & $\begin{array}{c}0.7269^{*} \\
(0.2501)\end{array}$ & $\begin{array}{c}0.5529 \\
(0.3274)\end{array}$ & $\begin{array}{r}0.8282^{*} \\
(0.3067)\end{array}$ \\
\hline Independent & $\begin{array}{c}1.8822^{*} \\
(0.4272)\end{array}$ & $\begin{array}{r}2.8239^{*} \\
(1.0235)\end{array}$ & $\begin{array}{c}1.5479 \\
(1.0589)\end{array}$ \\
\hline \multicolumn{4}{|l|}{ Residence } \\
\hline Rural & $\begin{array}{l}-0.1092 \\
(0.2028)\end{array}$ & $\begin{array}{l}-0.0868 \\
(0.2389)\end{array}$ & $\begin{array}{l}-0.1191 \\
(0.2123)\end{array}$ \\
\hline \multicolumn{4}{|l|}{ Ethnicity } \\
\hline NESB & $\begin{array}{c}0.4705 \\
(0.2365)\end{array}$ & $\begin{array}{c}0.4076 \\
(0.2727)\end{array}$ & $\begin{array}{c}0.1872 \\
(0.2636)\end{array}$ \\
\hline
\end{tabular}

* Asterisks represent estimates that are significant at least at the .05 level.

a The control group for both males and females comprises government school students who attended school in a metropolitan area and who had Australian-born fathers in a professional or managerial occupation. Mothers had attended secondary school.

b Explanation:

The main changes can be determined by comparing the numbers of significant predictors of school completion at each point in time. For example, the negative coefficient for skilled manual in 1988 shows that boys from this occupational background were significantly less likely to complete school, other things equal, than boys from professional and managerial backgrounds with the control characteristics. In 1990 the likelihood of school completion for boys from skilled manual backgrounds was not significantly different to the control group, but was again in 1994 . 
Table 4 Logistic regression modelling school completion for 1988, 1991 and 1994: Females

\begin{tabular}{|c|c|c|c|}
\hline & 1988 & 1991 & 1994 \\
\hline Control Female & $\begin{array}{c}1.1961^{*} \\
(0.3696)\end{array}$ & $\begin{array}{l}1.5961^{*} \\
(0.4237)\end{array}$ & $\begin{array}{c}1.9271^{*} \\
(0.4101)\end{array}$ \\
\hline \multicolumn{4}{|l|}{ Father's Occupation } \\
\hline Intermediate non-manual & $\begin{array}{l}-0.0626 \\
(0.4213)\end{array}$ & $\begin{array}{l}-0.2656 \\
(0.4987)\end{array}$ & $\begin{array}{l}-0.0438 \\
(0.4836)\end{array}$ \\
\hline Skilled Manual & $\begin{array}{l}-0.6408 \\
(0.3858)\end{array}$ & $\begin{array}{l}-0.5004 \\
(0.4396)\end{array}$ & $\begin{array}{l}-0.5216 \\
(0.4311)\end{array}$ \\
\hline Unskilled Manual & $\begin{array}{l}-1.1174^{*} \\
(0.3932)\end{array}$ & $\begin{array}{l}-0.6438 \\
(0.4540)\end{array}$ & $\begin{array}{l}-1.0834^{*} \\
(0.4426)\end{array}$ \\
\hline \multicolumn{4}{|l|}{ Mother's Education } \\
\hline University & $\begin{array}{c}0.6181 \\
(0.3825)\end{array}$ & $\begin{array}{c}0.3832 \\
(0.4219)\end{array}$ & $\begin{array}{c}0.7098 \\
(0.5020)\end{array}$ \\
\hline Other Post-secondary & $\begin{array}{c}0.2682 \\
(0.2837)\end{array}$ & $\begin{array}{c}0.1814 \\
(0.3455)\end{array}$ & $\begin{array}{c}0.2989 \\
(0.2907)\end{array}$ \\
\hline \multicolumn{4}{|l|}{ School Type } \\
\hline Catholic & $\begin{array}{r}0.5059^{*} \\
(0.2628)\end{array}$ & $\begin{array}{c}0.3945 \\
(0.4218)\end{array}$ & $\begin{array}{c}1.1494^{*} \\
(0.4193)\end{array}$ \\
\hline Independent & $\begin{array}{r}1.2066^{*} \\
(0.4479)\end{array}$ & $\begin{array}{r}1.3621^{*} \\
(0.6357)\end{array}$ & $\begin{array}{c}1.8406 \\
(1.0350)\end{array}$ \\
\hline \multicolumn{4}{|l|}{$\underline{\text { Residence }}$} \\
\hline Rural & $\begin{array}{l}-0.0611 \\
(0.2105)\end{array}$ & $\begin{array}{l}-0.2196 \\
(0.2499)\end{array}$ & $\begin{array}{l}-0.2843 \\
(0.2411)\end{array}$ \\
\hline$\frac{\text { Ethnicity }}{\text { NESB }}$ & $\begin{array}{c}0.6581^{*} \\
(0.2875)\end{array}$ & $\begin{array}{c}0.5640 \\
(0.3251)\end{array}$ & $\begin{array}{c}0.4466 \\
(0.3244)\end{array}$ \\
\hline
\end{tabular}

* Asterisks represent estimates that are significant at least at the .05 level.

a The control group for both males and females comprises government school students who attended school in a metropolitan area and who had Australian-born fathers in a professional or managerial occupation. Mothers had attended secondary school. 
By 1994, following the period of decline in school completion, some of the background variables again become significant. One change is father's occupation, with the figures indicating that boys from both skilled manual and unskilled manual backgrounds are significantly less likely to complete school compared to boys from professional and managerial origins. Another change is with school type. Whereas in 1991 differences between government and Catholic schools had become small, in 1994 attendance at a Catholic school significantly increased the likelihood of school completion.

In comparing the patterns for girls it has to be kept in mind that the school completion rates over the whole period were substantially higher than for boys. With stronger participation rates, the influence of different background factors was generally weaker. In 1988, other things equal, attending a non-Catholic private school or coming from a non-Englishspeaking background significantly increased chances of school completion while having a father in an unskilled manual job reduced the likelihood of school survival.

Other attributes were not significant determinants. In 1991, at the height of school completion rates, the relationships between social origin and school completion were much weaker. Ethnicity and father's occupation were no longer significant predictors of completion. The only variable to significantly affect school survival was attendance at a private non-Catholic school. The rate of downturn during the 1990s has been weaker for girls than for boys and therefore the patterns evident in 1991 tend to hold into 1994. One exception is the influence of school type. The decline in recent years has been strongest in government schools. Attendance at a Catholic school, other things equal, significantly increases the chances of school completion. Another exception is father's occupation. Girls with fathers in unskilled manual jobs were significantly less likely to survive to Year 12 compared to girls with fathers in professional and managerial occupations.

\section{DISCUSSION}

Several reasons may account for the trends documented in this report.

Recent years have seen considerable growth in vocational education and training. Some of this has been in secondary schools where a range of initiatives have included the integration of vocational education studies as accredited school courses, the development of schoolindustry link programs, and the introduction of cooperative programs with TAFE (Ainley and Fleming, 1995; Kennedy, Cumming and Catts, 1993). However, there has also been considerable growth in participation in TAFE vocational courses and in training provided by other agencies such as business colleges, industry skills centres and privately-run training institutions. The recent downturn in school completion may reflect an increase in the numbers of young people wanting to take advantage of alternative education and training opportunities.

In other words, school numbers may have declined but overall educational participation will have remained much the same. Supporting this view, TAFE enrolments in initial vocational courses (modules 3100-3500) have grown considerably. Across Australia they increased annually from 717,623 in 1990 to 835,811 in 1994 (ACVETS, 1995).

However, other evidence suggests that this growth has not originated from early school leavers. ABS estimates of participation in education show that the rates of participation in TAFE and other tertiary institutions for 16 and 17 year-olds have not grown appreciably during the early 1990s (Australian Bureau of Statistics, 1995). Indeed, the rates for 1994 were below those estimated for 1990 (see Table 5). Furthermore, the overall education participation rates for 16 and 17 year-olds have fallen annually since 1992, reinforcing the 
view that early school leavers are relying on direct entry to the labour market rather than on taking up places in post-compulsory education and training.

Another possible reason for the downturn in school completion of Australian teenagers is an increase in the number of available apprenticeships and traineeships. During the late 1980s the number of apprenticeships and traineeships grew steadily reaching record levels in 1990. The impact of the recession in 1991 caused the number of apprenticeship training positions to decline dramatically: commencements fell from 62,259 in the $1989 / 90$ financial year to 44,985 in 1990/91. The numbers fell again over the following 12 months to a low of 40,500 . When the economy began to pick up after the sharp recession of 1991/92, the number of apprenticeships built up again reaching 50,453 in the 1993/94 financial year. ${ }^{3}$ Because apprenticeships are a major source of employment for teenage males, the recovery in apprenticeship numbers in recent years may help explain why the decline in school completion has been stronger among males, particularly males from lower socioeconomic backgrounds, than for females. ${ }^{4}$ However, it has to be kept in mind that when apprenticeship numbers were expanding in the late 1980s, school completion rates were also rising. Furthermore, the drift away from school in the early 1990s began at the height of the recession when the number of indentures had fallen sharply. Therefore it is more likely that the recent growth in apprenticeship commencements has helped maintain rather than cause the trend away from school.

The fact that school participation rates for males and females reached their peak and began to decline at the onset of the 1991 recession suggests that an explanation which is based on changes in labour market opportunities or on developments in training opportunities alone is inadequate. An alternative explanation might be found in the changing views of young people on the value of remaining at school. One of the effects of the large expansion in school completion during the 1980s has been a devaluation in the benefits of Year 12. Not only has completion of Year 12 become much more widespread but also available to a broadening population of qualifiers. This tends to lessen its economic and social value. Because growth in post-school opportunities, in further education and employment, has not kept pace with the expansion in numbers of school users, there is a higher level of disappointment attached to school completion.

Table 5 Participation in Technical and Further Education of 16 year-olds: Australia, May 1991-1994*

\begin{tabular}{lccl}
\hline & TAFE & OTHER $^{1}$ & Participation rate $^{2}$ \\
\cline { 2 - 4 } & \multicolumn{3}{c}{ Males } \\
\cline { 2 - 4 } 1991 & 7,400 & 500 & 87.9 \\
1992 & 7,900 & 600 & 89.3 \\
1993 & 7,600 & 500 & 88.5 \\
1994 & 8,700 & 500 & 84.7 \\
& \multicolumn{3}{c}{ Females } \\
\cline { 2 - 4 } 1991 & 4,600 & 400 & 90.7 \\
1992 & 2,700 & 200 & 90.1 \\
1993 & 2,600 & 1,100 & 89.6 \\
1994 & 2,100 & 400 & 89.3 \\
\hline
\end{tabular}

1 Other includes business colleges, industry skill centres and other tertiary educational institutions

2 Education participation rate is calculated from the numbers of persons attending school, higher education, TAFE or other education institution as a percentage of all persons of a particular age group.

* Source: Australian Bureau of Statistics, Participation in Education series, May figures for 1991 to 1995. 
Unmet demand for places in higher education grows and, thanks to a larger pool of Year 12 graduates, a higher level of competition for available jobs. In effect the inflation in school use produces a decline in the employment and further education value of Year 12. On this view, therefore, attitudes towards longer education have changed because of a decline in the educational and employment benefits of Year 12 and the main impact has been on the new populations of school users because they have been least successful in translating school completion into higher education entry.

Related to the issue of judgements that young people make about the relevance of school are their experiences of school itself. To want to remain at school young people have to feel that the time and effort they put in is meaningful, rewarding and successful. Recent work suggests that the decline in school completion has been strongest in areas, and among groups, where failure in key subject areas has grown. Teese (1996) in a study of educational and economic indicators of regional disadvantage in Victoria found that across the state regions which experienced the biggest falls in school completion had also experienced increases during the 1990s in levels of VCE failure. The prevalence of high levels of unemployment in a region did not alter this pattern. It suggests that how well children are doing academically in school is a strong influence on their plans and behaviour, reinforcing the need for schools to find appropriate ways of maintaining high levels of general attainment and ensuring that young people from all backgrounds are able to reach those levels.

Whatever the reason for the recent decline in school completion, the trends identified in this report indicate the need for the continued monitoring of the numbers of young people completing school and their backgrounds. The downturn in use of school during the 1990s has been uneven. Differences have begun to grow between school systems, between geographical regions and between social groups. This is the case despite the great strides schools made over the preceding decade in extending the benefits of school to all and attempting to meet the challenge of expanding the range of activities of young people, and of their skills, productivity and expectations. Further work is needed to establish why this has now stalled.

\section{Endnotes}

It is worth noting that the expansion in Year 7 recruitment which non-Catholic schools continued to experience during the late 1980s occurred during a period of national decline in entry-level enrolments. It shows how unique this sector of schools is and why retention rates are not a good measure of their comparative performance.

2 The term 'completion rate' is used here simply to refer to the proportions of students remaining to Year 12. This is different to its use elsewhere. For example, in the annual Australian National Report completion rates are calculated as the ratio of Year 12 completions to the population of potential Year 12 students.

3 These figures were kindly provided by John Foyster of the National Centre for Vocational Education Research.

4 Figures provided by DEETYA show that the number of Australian Traineeship commencements also increased over this time: from 9443 in the 1990/91 financial year, 9216 in 1991/ 92 to 16140 in 1993/94.

$5 \quad$ Evidence on poorer higher education transition rates of children from lower socioeconomic backgrounds is provided in the report by Williams, Long, Carpenter and Hayden (1993b) on higher education entry, and a report by Lamb (1994) on the benefits of completing Year 12 in Australia. 


\section{REFERENCES}

Ainley, J., Batten, M. \& Miller, H. (1984a). Staying at high school in Victoria. Research Monograph No. 23. Hawthorn, Victoria: Australian Council for Educational Research.

Ainley, J., Batten, M. \& Miller, H. (1984b). Patterns of retention in Australian government schools. Research Monograph No. 27. Hawthorn, Victoria: Australian Council for Educational Research.

Ainley, J. \& Fleming, M. (1995). School-industry programs: national survey 1995. Sydney: Australian Student Traineeship Foundation.

Australian Bureau of Statistics (1995). Schools, Australia 1995. Catalogue No. 4221.0. Canberra: Australian Bureau of Statistics.

Australian Bureau of Statistics (1995). Participation in Education, Australia 1995. Catalogue No. 4221.0. Canberra: Australian Bureau of Statistics.

Australian Committee on Vocational Education and Training Statistics. (1995). Selected Vocational Education and Training Statistics Canberra: National Centre for Vocational Education Research.

Australian Education Council (1991). National report on schooling in Australia: Statistical annex. Melbourne: Australian Education Council and Curriculum Corporation.

COSTAC (1986) Apprenticeship Statistics, 1975-76 to 1984-85. Commonwealth-State Training Advisory Committee, Canberra: AGPS.

Department of Employment, Education and Training (1987). Completing secondary school in Australia: A socioeconomic and regional analysis. Canberra: AGPS.

Department of Employment, Education and Training (1995). National project on repeating Year 12 students, Report prepared by Roy Morgan Research for the Commonwealth Department of Employment, Education and Training. Canberra: Morgan Research.

Kennedy, K., Cumming, J. \& Catts, R. (1993). Vocational education in secondary schools: a review of the literature. Toowoomba: University of Southern Queensland (mimeo).

Lamb, S. (1994) "Dropping out of school in Australia: recent trends in participation and outcomes", Youth and Society, 26 (2) 194-222.

Lamb, S. (1994) Completing school in Australia: changes in participation and outcomes. Report to the Department of Employment, Education and Training. Melbourne: Youth Research Centre, University of Melbourne.

Miller, P. \& Volker, P. (1989). Socio-economic influences on educational attainment: Evidence and implications for the tertiary education finance debate. Australian Journal of Statistics. 31A, 47-70.

National Board of Employment, Education and Training (1991). Toward a national education and training strategy for rural Australians: report of the National Board of Employment, Education and Training. Canberra: AGPS.

Najman, J. M. \& Bampton, M. (1991). An ASCO based occupational status hierarchy for Australia: A research note. Australia and New Zealand Journal of Sociology. 27 (2) 218-231.

Power, C. (1984). Factors influencing retentivity and satisfaction with secondary schooling. Australian Journal of Education. 28 (2) 115-125.

Teese, R. (1983). "The growth and decline of the Victorian Government Secondary School, 1954-81", Melbourne Working Papers 4, Melbourne: Department of Education, University of Melbourne, pp 126-210.

Teese, R. (1996). "Educational and economic indicators of regional disadvantage amongst young people in Victoria, 1992-94" Paper presented at the Australian Vocational Training System Conference, Mt Macedon, 14-15 March 1996.

Teese, R., Polesel, J. \& McLean, G. (1992). Completing school in Victoria: Retention before and during recession: A regional analysis. Parkville: Department of Social and Educational Studies, University of Melbourne. 
Williams, T. (1987) Participation in education, ACER Research Report No. 30. Hawthorn, Victoria: Australian Council for Educational Research.

Williams, T., Long, M., Carpenter, P. \& Hayden. M. (1993a). Year 12 in the 1980's. Canberra: AGPS.

Williams, T., Long, M., Carpenter, P. \& Hayden. M. (1993b). Entering higher education in the 1980's. Canberra: AGPS. 